U.S. Department

of Transportation

National Highway

Traffic Safety

Administration

DOT HS 811535

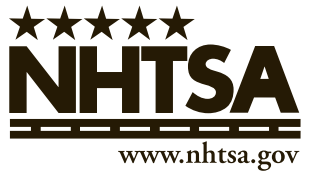

September 2011

\title{
Determining the Relationship of Primary Seat Belt Laws to Minority Ticketing
}




\section{DISCLAIMER}

This publication is distributed by the U.S. Department of Transportation, National Highway Traffic Safety Administration, in the interest of information exchange. The opinions, findings, and conclusions expressed in this publication are those of the authors and not necessarily those of the Department of Transportation or the National Highway Traffic Safety Administration. The United States Government assumes no liability for its contents or use thereof. If trade names, manufacturers' names, or specific products are mentioned, it is because they are considered essential

to the object of the publication and should not be construed as an endorsement. The United States Government does not endorse products or manufacturers.

\section{APA Format Citation:}

Tison, J., Williams, A. F., Chaudhary, N. K., \& Nichols, J. L. (2011, September). Determining the Relationship of Primary Seat Belt Laws to Minority Ticketing. (Final Report. Report No. DOT HS 811 535). Washington, DC: National Highway Traffic Safety Administration. 
Technical Report Documentation Page

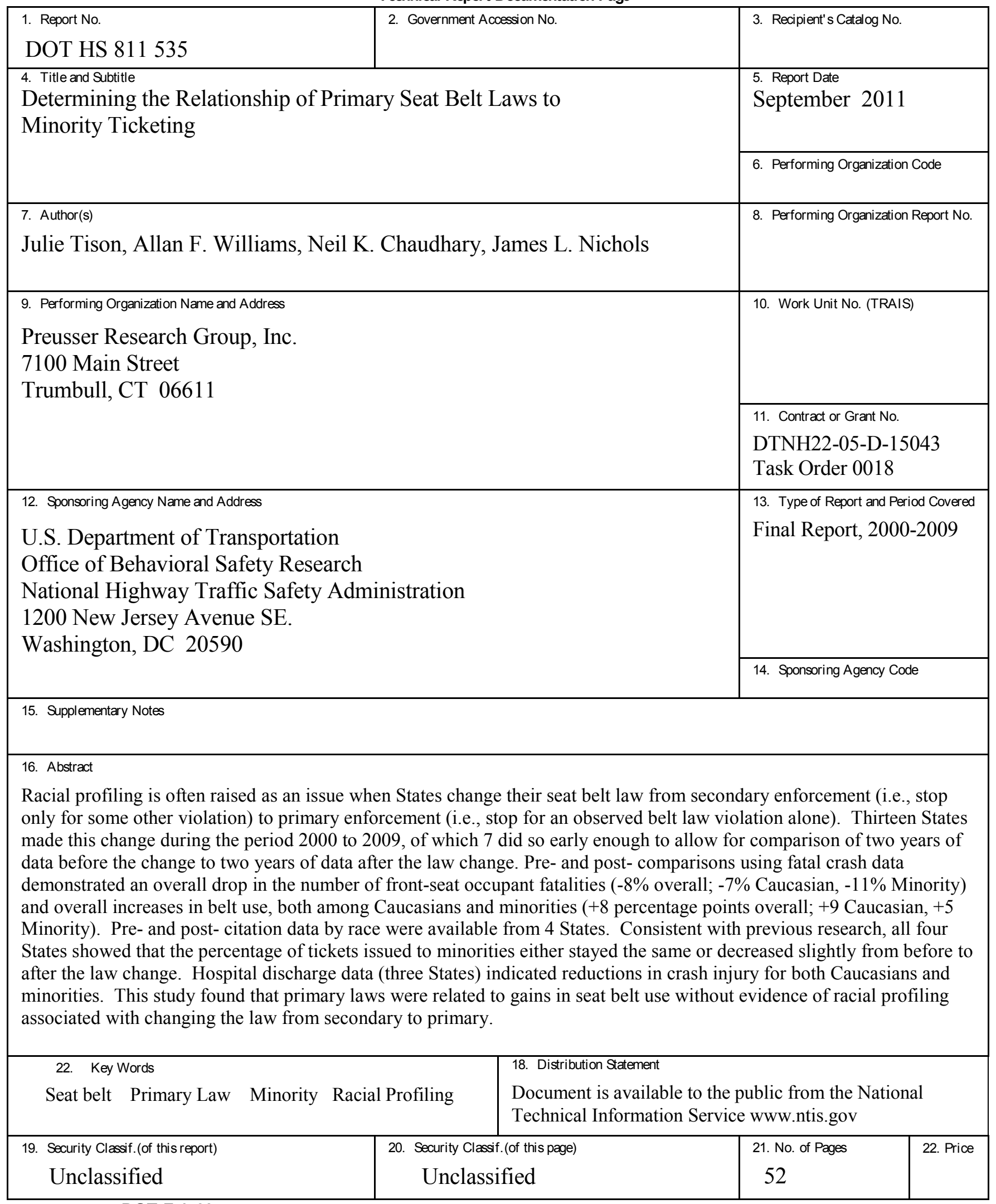

Form DOT F 1700.7 (8-72) $\quad$ Reproduction of completed page authorized 


\begin{tabular}{l|l}
\hline \hline CONTRACTOR & $\begin{array}{l}\text { CONTRACT NUMBER } \\
\text { DTNH22-05-D-15043 } \\
\text { Task Order 0018 }\end{array}$ \\
\hline $\begin{array}{l}\text { REPORT TITLE } \\
\text { Determining the Relationship of Primary Seat Belt Laws to Minority Ticketing }\end{array}$ & $\begin{array}{l}\text { REPORT DATE } \\
\text { September 2011 }\end{array}$ \\
\hline REPORT AUTHOR(S) & \\
\hline
\end{tabular}

Julie Tison, Allan F. Williams, Neil K. Chaudhary, James L. Nichols

\section{BACKGROUND}

Conversions from secondary to primary seat belt enforcement have produced important safety benefits. However, the conversions inevitably renewed concerns about the possibility of differential enforcement involving minority groups. Early studies reported no evidence of systematic differential enforcement involving minority groups following the change. Since those earlier studies, 17 additional States have upgraded to primary enforcement. While approval ratings for primary laws are high, issues of minority harassment, differential enforcement, racial profiling, and "driving while Black" still arise in discussions of converting seat belt laws to primary enforcement status. The present study extends the earlier work, investigating changes in fatality and injury rates in minority and majority populations after States switch from secondary to primary enforcement, as well as investigating evidence of differential enforcement.

\section{OBJECTIVE}

This new study is based on a larger sample of States from different regions of the country that have more recently converted to primary enforcement laws. This study addressed the following questions:

1) How did conversions to primary enforcement affect belt use among fatally injured front seat occupants, by race/ethnicity?

2) How did conversions affect seat belt citations by race/ethnicity?

3) How did conversions affect the number of hospital admissions for injuries from motor vehicle crashes?

4) How were issues of differential enforcement for minority populations covered in news reports?

5) How did legislative bills to introduce primary enforcement address the issue of differential enforcement?

\section{METHODS}

Archival data were collected in order to evaluate the impact of upgrades to primary seat belt laws. Although 13 States upgraded their laws in the study period, only 7 of the 13 had sufficient pre- and post- data available for analysis (two years before and two years after). Data from the Fatality Analysis Reporting System (FARS) were used to evaluate overall changes in belt use in 7 States, before and after the law change. The magnitude of 
change in belt use was also compared across racial categories, before and after the law change. The number of seat belt citations were provided by most participating States and the distribution of citations across races was used to assess potential differential enforcement of the law based on race, before and after the law upgrade. Hospital discharge data were obtained from a number of States and allowed for a comparison of the number and rate of injury by race, before and after implementation of a primary seat belt law. News reports about the law change were collected from 6 of the 13 States that upgraded their seat belt law between 2000 and 2009. Full articles were collected for the two-year period leading to the law change and were coded for content. Copies of the actual primary seat belt law were obtained for each of the 13 States and were reviewed to determine if the law specifically mentioned race or racial profiling.

\section{RESULTS}

\section{Belt Use in Fatal Crashes}

Thirteen States upgraded their seat belt laws since 2000. Analyses of effects of law upgrade within the States (i.e., pre- to post-law change) were conducted on a subset of these 13 States. Analyses were based on known and proper belt use by fatally injured outboard front seat passenger vehicle occupants, age 16 and above. The overall number of fatalities in the study States dropped by $8.1 \%$ from pre- to post- upgrade and similar decreases were observed for the major racial groups. From pre- to post-, Caucasians showed a $7.4 \%$ decrease in fatalities and minorities showed an $11.3 \%$ decrease in fatalities. The African-American subgroup showed a $10.1 \%$ decrease, and the Other subgroup, representing only $2 \%$ of all fatalities, showed a $19.9 \%$ decrease. Chi-square analyses indicated that the overall decrease in fatalities was significant. Caucasians and minorities showed a similar decrease in number of fatalities pre- to post-law change.

Number of Fatalities, Pre- Versus Post-

\begin{tabular}{|l|r|r|r|r|r|}
\hline \multirow{2}{*}{ All Fatalities } & \multicolumn{2}{|c|}{ Number of Fatalities } & \multirow{2}{*}{ \% Change } & \multicolumn{2}{c|}{ \% Total Fatalities } \\
\cline { 2 - 3 } \cline { 5 - 6 } & Pre & Post & Pre & \multicolumn{1}{c|}{ Post } \\
\hline Caucasian & 8,342 & 7,668 & $-8.1 \%$ & $100 \%$ & $100 \%$ \\
\hline Minority (incl. African-Am.) & 6,894 & 6,383 & $-7.4 \%$ & $83 \%$ & $83 \%$ \\
\hline African-American & 1,448 & 1,285 & $-11.3 \%$ & $17 \%$ & $17 \%$ \\
\hline Other & 1,282 & 1,152 & $-10.1 \%$ & $15 \%$ & $15 \%$ \\
\hline
\end{tabular}

The overall proportion of belt use in fatalities increased by 8 percentage points, from $34 \%$ to $42 \%$, pre- to post-, respectively. Belt use in fatally injured Caucasian occupants increased from $35 \%$ pre- to $44 \%$ post-, a 9-percentage-point increase $(p<.0001)$. Fatally injured African-American occupants also showed an increase in belt use from $28 \%$ to $32 \%$, pre- to post-, respectively $(p=.01)$. Caucasians showed an increase in belt use in all 7 States, whereas the minority group showed an increase in 5 of the 7 States. 


\section{Belt Citations}

Four States provided seat belt citation data covering the period before and after the law upgrade. During the pre-period, an average of $11 \%$ of citations were issued to minorities in Kentucky, compared to an average of $10 \%$ after the law upgrade. In Mississippi, minorities were issued $55 \%$ of citations on average before the law; this declined to $53 \%$ after implementation of the primary seat belt law. In South Carolina, minorities received an average of $38 \%$ of seat belt citations before the law and $37.5 \%$ of citations after the law. The pattern in Tennessee was also stable with minorities being issued $13 \%$ of citations before the law change, and an average of $13 \%$ after the law change. Thus seat belt citation data reveal no real change in pattern of citations across races before and after the law change.

Percentage Seat Belt Citations by Race

\begin{tabular}{|l|l|rr|rr|}
\hline \multirow{2}{*}{ State } & \multirow{2}{*}{ Race } & \multicolumn{2}{|c|}{ Pre } & \multicolumn{2}{c|}{ Post } \\
\cline { 3 - 6 } & & 2 years & 1 year & 1 year & 2 years \\
\hline Kentucky & Caucasian & $89 \%$ & $90 \%$ & $90 \%$ & $90 \%$ \\
& Minority & $11 \%$ & $11 \%$ & $10 \%$ & $10 \%$ \\
\hline Mississippi & Caucasian & $43 \%$ & $47 \%$ & $47 \%$ & $47 \%$ \\
& Minority & $57 \%$ & $53 \%$ & $53 \%$ & $53 \%$ \\
\hline South Carolina & Caucasian & $62 \%$ & $62 \%$ & $63 \%$ & $62 \%$ \\
& Minority & $38 \%$ & $38 \%$ & $37 \%$ & $38 \%$ \\
\hline Tennessee & Caucasian & n/a & $87 \%$ & $87 \%$ & $88 \%$ \\
& Minority & n/a & $13 \%$ & $14 \%$ & $12 \%$ \\
\hline
\end{tabular}

\section{Injuries}

The 7 study States were contacted in order to obtain hospital discharge data for each State's pre- and post-law change period. Data from 3 of these States were obtained: Kentucky, South Carolina, and Washington. Ideally, the race of each patient would have been indicated and used to assess any changes in rate of injuries by race from pre- to post-law upgrade. Unfortunately, such data were only available for South Carolina. In Washington and Kentucky, ZIP codes were used as a proxy to race. In both States where ZIP codes were used as a proxy for actual race there was a greater decrease, albeit nonsignificant, in the minority admissions than in the White admissions. In South Carolina, where the actual race was known, there was also a decrease in admissions from pre- to post-law change. The decrease was lower among African-Americans than Caucasian patients, but this difference between races was not significant.

\section{News Report}

Almost 200 news articles were collected from 6 States: Arkansas, Florida, Minnesota, and Wisconsin - all of which upgraded in 2009- as well as Maine and Alaska, which upgraded in 2007 and 2006, respectively. Racial profiling was mentioned in $43.5 \%$ of articles while $56.5 \%$ of articles made no mention of it. Approximately one-third of news reports presented arguments favorable to the primary seat belt law (34\%); 8\% presented arguments unfavorable to the primary law upgrade; $35 \%$ reported a balanced view (i.e., judged to present both favorable and unfavorable arguments); and 24\% were neutral. There were wide variations between States in percentage of articles mentioning racial profiling. Some States made no mention of racial profiling. 


\section{CONCLUSION}

Earlier research on conversion of seat belt laws to primary enforcement indicated that minorities (in most cases African-Americans) perceive stricter enforcement than Caucasians and are more likely to believe they will get a ticket if unbelted. The present study has an advantage over earlier work in that it is based on a greater number of States. The States are located in various regions of the country providing a broad reflection of experience with primary laws in the United States.

The results show clearly the advantages of primary belt laws. Seat belt use increased in each of the 7 States studied, with an average gain of 8 percentage points. Significant gains were made among Caucasians, African-Americans, and other minorities. However, the gains were not proportionately greater in the minority groups, and African-Americans had substantially lower belt use than Whites both when the laws were secondary and when they were primary. The information on changes in hospital admissions was obtainable from fewer States, but it also showed the advantage of primary laws. There were decreases in hospital admissions for all groups, but data limitations hampered the comparisons and the results were inconclusive.

The numbers of citations for nonuse of seat belts increased substantially in every State that switched to primary, and increases occurred in all groups. However, the percentage of citations received by each group changed very little.

Most of the news articles published before passage of the primary laws were favorable about primary laws. State laws were mostly silent on the subject of differential enforcement. A few of the laws spelled out specific guidelines for enforcement, generally indicating criteria for making stops or what could or could not be done once the stop was made. Only the Florida law called for the establishment of departmental plans designed to prohibit racial profiling practices.

The change to primary laws was associated with gains in belt use in all groups. While the overall number of seat belt citations increased after the primary laws went into effect, the proportion of citations by race remained about the same after the law change. There was no evidence of racial profiling associated with changing the law from secondary to primary enforcement. 


\section{TABLE OF CONTENTS}

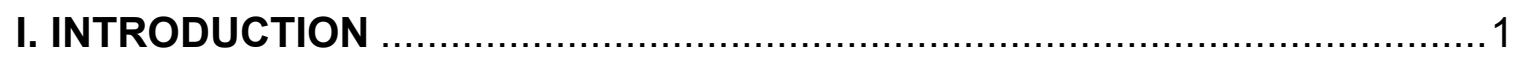

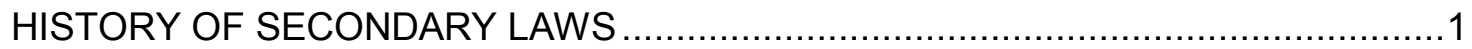

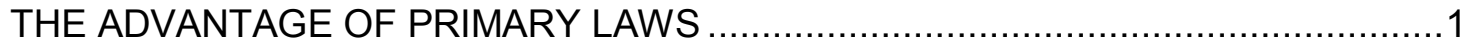

CONVERSIONS TO PRIMARY ENFORCEMENT ……................................... 1

Do Primary Law Conversions Promote Differential Enforcement? .........................2

Seat Belt Use After Changing to Primary Enforcement........................................ 4

Summary of Findings From Early Studies...................................................

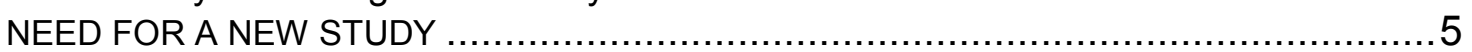

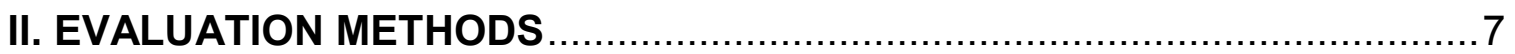

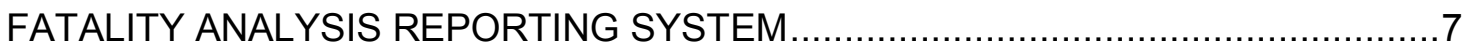

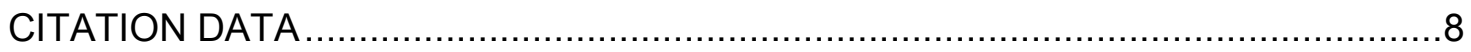

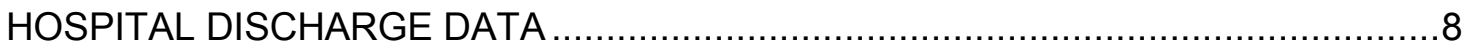

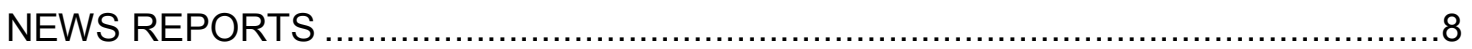

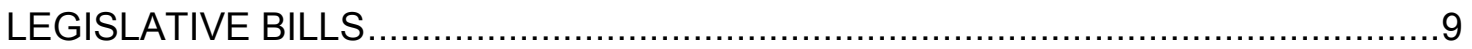

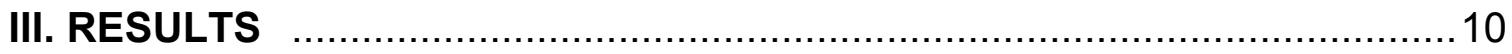

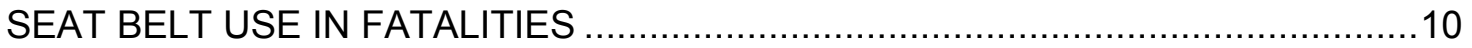

Primary Versus Secondary Law States..................................................... 10

Pre- Versus Post-Law Upgrade ................................................................

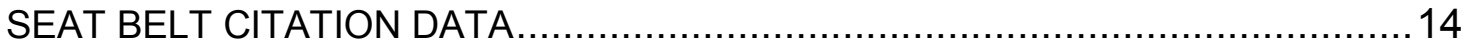

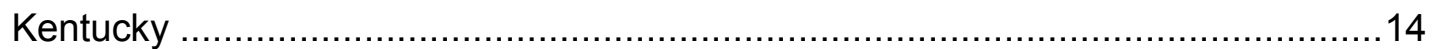

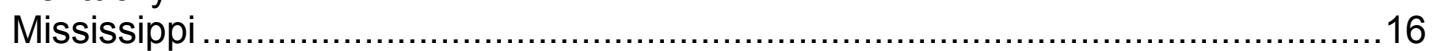

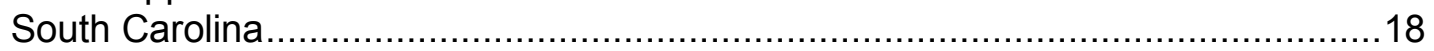

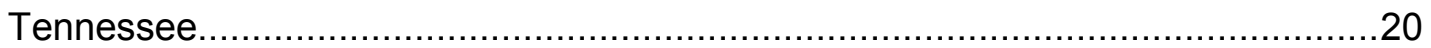

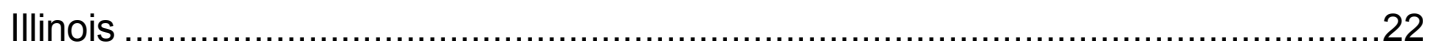

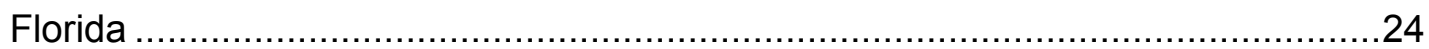

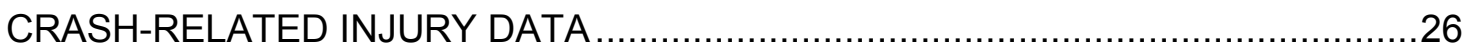

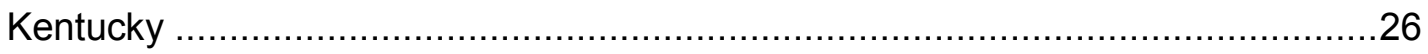

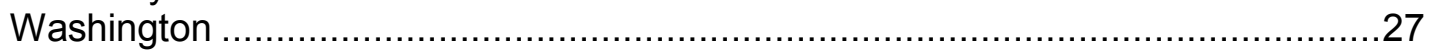

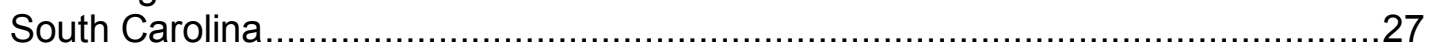

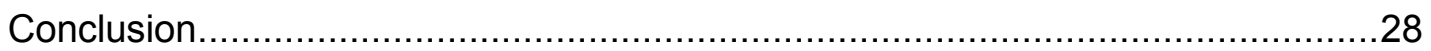

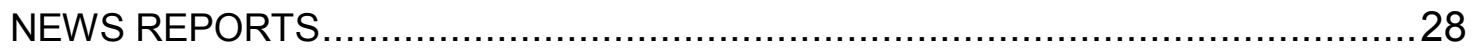

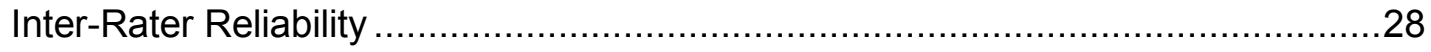

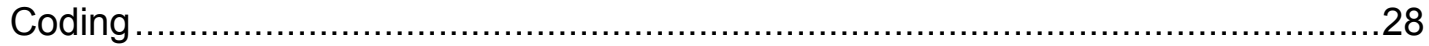

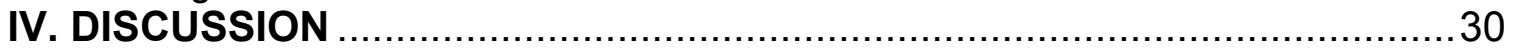

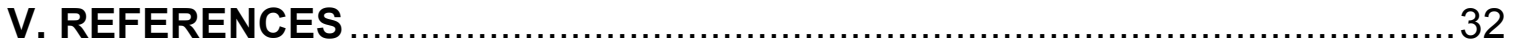

APPENDIX A. STATES BY SEAT BELT LAW ENFORCEMENT STATUS,

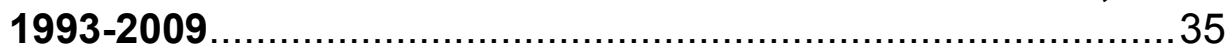

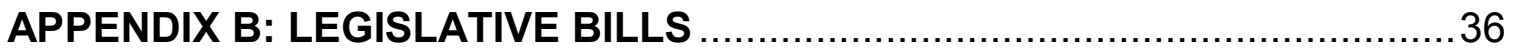

APPENDIX C. NEWS REPORTS CODING SHEET ...............................40 


\section{INTRODUCTION}

\section{HISTORY OF SECONDARY LAWS}

The first State seat belt use law in the United States was enacted in New York in 1984, spurred by a coalition led by the medical community. The New York law allowed for primary, or standard, enforcement, as do belt use laws in all other countries with seat belt laws. Weeks later, the U. S. Department of Transportation issued a rule including a provision that passive restraints would not be required if a certain number of States passed belt use laws meeting specified minimum criteria. In response, the automobile industry funded a massive campaign to enact State seat belt laws. The ensuing flurry of lawmaking resulted in many laws with secondary enforcement provisions (Haseltine, 2001). The DOT rulemaking had not anticipated this development and did not specify how laws were to be enforced.

New Jersey was the second State with a belt use law, in 1985. Due to concerns that the law might be used to harass minorities, New Jersey added a provision that prohibited officers from stopping vehicles solely because of a belt violation. A seat belt ticket could not be issued unless the vehicle was stopped for some other violation. Most other States followed New Jersey's lead, partly as a way of gaining the necessary votes. As originally passed, 39 of the 49 belt use laws in the United States included secondary enforcement provisions.

\section{THE ADVANTAGE OF PRIMARY LAWS}

Once belt use laws had been in place for a few years, several things became evident. One was that a law by itself was insufficient to increase belt use adequately, and that enforcement campaigns modeled on those used in Canada would be needed to boost use rates (Williams \& Wells, 2004). Research studies established that converting nonusers was particularly important because they had characteristics that put them at higher crash risk than users (Preusser, Williams, \& Lund, 1991). It also became clear that the easier-to-enforce primary belt use laws resulted in substantially higher belt use than did secondary laws (Campbell, 1988), and that enforcement campaigns were more straightforward if stops could be made directly for belt law violations. Surveys indicated that the public was well aware of the enforcement provisions, and that non-users in secondary States recognized their protected status. Motorists in primary States were much more likely to think they would be stopped and cited for a belt law violation than those in secondary States (Cammisa, Williams, \& Ferguson, 2000). This combination of factors provided motivation for converting from secondary to primary enforcement status.

\section{CONVERSIONS TO PRIMARY ENFORCEMENT}

In the years 1993 to 2009, 22 States and the District of Columbia converted from secondary to primary enforcement (see Appendix A for States and conversion dates). The 
positive results of conversions to primary have been extensively documented (e.g., DinhZarr et al., 2001; Hedlund, Gilbert, Ledingham, \& Preusser, 2008). As summarized by Nichols and Ledingham (2008), in the 18 States that made this conversion between 1993 and 1997, there was a median 13- to 16-percentage-point increase in seat belt use. In a study of States that converted to primary enforcement, annual driver fatality rates decreased by $7 \%$ after accounting for possible economic effects and general time trends (Farmer \& Williams, 2005). Cost savings, primarily involving medical care, are estimated to be $\$ 158$ million per State annually (Nichols \& Ledingham, 2008).

\section{Do Primary Law Conversions Promote Differential Enforcement?}

Conversions to primary enforcement have produced important safety benefits. However, the conversions inevitably renewed concerns about the possibility of differential enforcement involving minority groups. The National Highway Traffic Safety Administration commissioned studies in 6 of the initial jurisdictions to make the change. These included the first three States to switch to primary enforcement: California, in 1993 (Ulmer, Preusser, \& Preusser, 1994); Louisiana, in 1995 (Preusser \& Preusser, 1997); and Georgia, in 1996 (Ulmer, Preusser, \& Preusser, under review). A subsequent study addressed Maryland, Oklahoma, and the District of Columbia, all converting in 1997 (Solomon, Preusser, \& Nissen, 2001).

The initial study in California mainly addressed the extent to which belt use changed following the conversion. Observational studies indicated a large increase, from 58 to 76 percent. The focus was not on race/ethnicity issues, but surveys of motorists renewing or applying for licenses at Department of Motor Vehicle (DMV) offices revealed some striking differences in perceptions of enforcement. Specifically, Hispanics, the dominant minority in California, were much more likely than Caucasians to perceive a "high likelihood" of receiving a ticket for not wearing a seat belt ( $71 \%$ versus $45 \%)$, and to judge enforcement by the California Highway Patrol as "very strict" (58\% versus $34 \%$ ). These results raised the specter of differential enforcement, although when asked if they had received a ticket, an equal percentage of Hispanics and Caucasians (13\%) replied affirmatively.

The later studies of conversions to primary were carried out in States where African-Americans were the dominant minority. Information was obtained from Caucasians and African-Americans on perceptions of enforcement, self-reported receipt of seat belt citations, self-reported changes in belt use, official data on citations, and observed seat belt use. Data on citations and observed belt use were not always available statewide, but in some cases could be obtained from local communities.

The results, summarized in Tables 1-3, showed a consistent pattern across the five jurisdictions. In terms of perceptions of enforcement, the results echoed those found among Hispanics in California. That is, in all five jurisdictions, African-Americans - by a wide margin - perceived stronger enforcement than Caucasians, in terms of their chances of getting a ticket if unbelted, and in how strict police enforcement was (Table 1). Yet, as indicated in Table 2, the proportions of African-Americans and Caucasians who said they had ever received a belt citation for non-use differed little. The exception was in the 
District of Columbia, where 13\% of African-Americans and 7\% of Caucasians said they had been cited. This difference was not statistically significant but is suggestive of a real difference. However, it cannot be interpreted as a possible effect of the conversion to primary, since the citation could have been received when the law was secondary. It also cannot be known if this is a possible result of racial profiling in general without information on belt use by race in the District of Columbia, which is unavailable. For instance, if belt use were much lower among African-Americans than Caucasians, a higher citation rate among the former would be expected.

Table 1. DMV Survey Respondents: Perceptions of Enforcement (\% agree)

\begin{tabular}{|c|c|c|c|c|}
\hline & & $\begin{array}{l}\text { High Ticket } \\
\text { Likelihood }\end{array}$ & $\begin{array}{c}\text { State Police } \\
\text { Strictly Enforce }\end{array}$ & $\begin{array}{l}\text { Local Police } \\
\text { Strictly Enforce }\end{array}$ \\
\hline \multirow[t]{2}{*}{ Louisiana } & African-Americans & $34 \%$ & $37 \%$ & $30 \%$ \\
\hline & Caucasians & $25 \%$ & $22 \%$ & $18 \%$ \\
\hline \multirow{2}{*}{ Georgia } & African-Americans & $45 \%$ & $34 \%$ & $29 \%$ \\
\hline & Caucasians & $36 \%$ & $25 \%$ & $18 \%$ \\
\hline \multirow[t]{2}{*}{ Oklahoma } & African-Americans & $51 \%$ & $29 \%$ & $27 \%$ \\
\hline & Caucasians & $38 \%$ & $21 \%$ & $19 \%$ \\
\hline \multirow[t]{2}{*}{ Maryland } & African-Americans & $50 \%$ & $42 \%$ & $40 \%$ \\
\hline & Caucasians & $42 \%$ & $26 \%$ & $22 \%$ \\
\hline \multirow{2}{*}{$\begin{array}{l}\text { District of } \\
\text { Columbia } \\
\text { to State police }\end{array}$} & African-Americans & $42 \%$ & * & $24 \%$ \\
\hline & Caucasians & $14 \%$ & * & $4 \%$ \\
\hline
\end{tabular}

Table 2. Percentage Reporting Having Received a Seat Belt Citation

\begin{tabular}{|l|c|c|}
\hline \multicolumn{1}{|c|}{ State } & African-Americans & Caucasians \\
\hline Louisiana & $8 \%$ & $8 \%$ \\
Georgia & $8 \%$ & $8 \%$ \\
Oklahoma & $7 \%$ & $9 \%$ \\
Maryland & $16 \%$ & $14 \%$ \\
District of Columbia & $13 \%$ & $7 \%$ \\
\hline
\end{tabular}

A more meaningful indicator of differential enforcement triggered by converting to primary enforcement is the extent to which the proportion of tickets issued to AfricanAmericans changed from before to after the conversion. Table 3 presents this information for the three States where it was available. The overall number of tickets issued for nonuse of belts increased in all jurisdictions with primary enforcement, as would be expected. However, the proportion of tickets issued to African-Americans was lower under primary enforcement in 2 of the States (Louisiana and Georgia), and was about the same in Maryland, with $27 \%$ of the tickets to African-Americans under secondary enforcement and $26 \%$ after conversion to primary enforcement. Unfortunately, data from the District of Columbia were not available to help clarify the difference in self-reported ticketing. 
Table 3. Percentage of Citations Issued to African-Americans Before and After Primary Law in Effect

\begin{tabular}{|l|c|c|}
\hline \multicolumn{1}{|c|}{ State } & Before Law Change & After Law Change \\
\hline Louisiana & $12 \%$ & $5 \%$ \\
Georgia & $36-45 \%$ & $29 \%$ \\
Maryland & $27 \%$ & $26 \%$ \\
\hline
\end{tabular}

\section{Seat Belt Use after Changing to Primary Enforcement}

Studies have shown increases of 10 percentage points or more in overall belt use (Preusser \& Preusser, 1997; Solomon, Preusser, \& Nissen, 2001). Self-reported data suggested that belt use increased more among African-Americans than Caucasians. That is, in Maryland, 54\% of African-Americans and 40\% of Caucasians said that their belt use increased with the conversion to primary enforcement, as did $60 \%$ of AfricanAmericans versus 51\% of Caucasians in Oklahoma, and $60 \%$ of African-Americans compared with only $24 \%$ of Caucasians in the District of Columbia. Data on observed belt use by race, where available, provided confirmation of a greater increase among African-Americans. For example, in Maryland, observed belt use by African-Americans after the conversion was $93 \%$ compared with $91 \%$ among Caucasians, whereas under secondary enforcement belt use for African-Americans was several percentage points lower than among Caucasians. In Louisiana, belt use by African-Americans was 11 percentage points lower than for Caucasians under primary enforcement, but it had been 18 percentage points lower under secondary enforcement. In Oklahoma, belt use under primary enforcement was $66 \%$ for both groups, although there was no available measure of belt use prior to the conversion.

The increased belt use by African-Americans in primary enforcement States helps to explain the mixed results found in other surveys of racial differences in observed belt use. Surveys conducted in the late 1990s typically found that African-Americans had lower use rates than Caucasians (NHTSA, 2000; Ellis et al, 2000). Primary enforcement appears to eliminate this difference, or even reverse the pattern. For example, in North Carolina, a primary enforcement State, belt use by Caucasians was substantially higher than among African-Americans before the law. In most years since the law, belt use by African-Americans has exceeded the use rate among Caucasians (Reinfurt, 2000). In an observational survey conducted in two cities with secondary laws (Boston, Chicago) and two cities with primary laws (Houston, New York City), there were no clear differences in belt use between African-Americans and Caucasians in primary cities. In secondary cities, African-Americans were less likely to be belted than Caucasians, among populations both with and without college degrees (Wells, Williams, \& Farmer, 2002). 


\section{Summary of Findings from Early Studies}

Studies have shown that minorities perceive stricter enforcement than Caucasians, and were more likely to believe that they will get a ticket if unbelted (Preusser \& Preusser, 1997; Ulmer, Preusser, \& Preusser, under review; Solomon, Preusser, \& Nissen, 2001). A survey in North Carolina also indicated that African-Americans were more sensitive than Caucasians to seat belt enforcement (Benjamin, Price, \& Reinfurt, 1996). As a result, African-Americans were more likely than Caucasians to increase their use of seat belts once the conversion to primary enforcement was made. Although ticketing increased with primary enforcement, there was no evidence of a change in the distribution of citations across racial groups. The proportion of the total tickets that were issued to AfricanAmericans decreased following passage to primary enforcement. Part of the reason for this could be a result of their proportionately greater increase in the use of belts. Whatever the case, primary enforcement resulted in higher belt use in general, particularly among African-Americans, and a more uniform number of citations across racial groups and greater protection for motor vehicle occupants.

Differential enforcement is clearly undesirable. What makes seat belt laws work is the heightened perception that they are being strictly enforced. Primary laws enhance the perception of enforcement in general, thereby motivating people to obey an important law. Notably, it is not only primary laws that motivate belt use among minority groups. It has also been found that in enforcement campaigns in general, belt use increases are greater among Hispanics and African-Americans than among Caucasians (Glassbrenner, 2003; Nichols, 2003).

\section{NEED FOR A NEW STUDY}

Since the studies in the first group of States to convert to primary laws, 17 other States have taken this step. There has been no reported evidence of systematic differential enforcement involving minority groups. In many States, minority organizations and minority individuals have been in the forefront in support of the change, and overall approval ratings for primary laws are higher among Hispanics (74\%) and AfricanAmericans (67\%) than among Caucasians (62\%) (NHTSA, 2008). In some States a civil liberties provision was put in the law that explicitly addressed the potential for harassment.

Despite the high approval ratings, issues of minority harassment, differential enforcement, racial profiling, and "driving while Black" still arise in discussions of converting seat belt laws to primary enforcement status. The earlier studies established the heightened enforcement sensitivity of minority groups in response to primary laws and the resultant increases in belt use. The present study extends the earlier work, in particular investigating bottom line effects: changes in injury rates in minority and majority populations after switching from secondary to primary. This new study is based on a larger sample of States from different regions of the country that have more recently

converted to primary. It provides a thorough analysis of the effects of the conversions and 
guidance to the 19 States still operating under secondary enforcement rules (see Appendix A). The following main questions were addressed.

- How did conversions to primary enforcement affect belt use among fatally injured front seat occupants, by race/ethnicity?

- How did conversions to primary enforcement law affect seat belt citations by race/ethnicity?

- How did conversions to primary enforcement affect crash-related injuries and fatalities by race/ethnicity?

- How did news reports about the implementation of primary enforcement address issues of differential enforcement for minority populations?

- How did legislative bills to introduce primary enforcement address the issue of differential enforcement?

All 13 States that switched to primary after 2000 were included. Seven had sufficient post-law data to conduct pre-post- analyses (Delaware, Illinois, Kentucky, Mississippi, South Carolina, Tennessee, and Washington). Others that made the change in very recent years were studied only in terms of news reports and legislative bills (Florida, Arkansas, Minnesota, Wisconsin, Maine, and Alaska). 


\section{EVALUATION METHODS}

Archival data were collected in order to evaluate the impact of an upgrade to a primary seat belt law on belt use of minority groups. Data of interest include proportion of belted fatalities, number of seat belt citations, number and severity of injuries, news reports and legislative bills.

\section{FATALITY ANALYSIS REPORTING SYSTEM}

Belt use was tracked across time and across States using data obtained from the Fatality Analysis Reporting System (FARS), which provides information regarding belt use among fatally injured passenger vehicle occupants. One major advantage of using FARS data is that race information is generally available. Belt use rates in fatal crashes are lower than observed rates, in part because belts prevent some fatalities, but also because individuals more likely to be in potentially fatal crashes are less likely to use seat belts. As such, belt use based on FARS data are closely related to seat belt use rates in potentially fatal crashes, which are the situations where belt use is most important. FARS was used to evaluate overall changes in belt use in 7 States, before and after the law change. Magnitude of change in belt use was also compared across racial categories, preand post-law change. Changes in overall belt use and across races were also compared between primary and secondary law States.

Rates of belt use among fatally injured passenger vehicle occupants were used as an estimate of belt use and were compared across race and time. FARS data were used to identify changes in belt use by comparing the two-year period before the law change to the two-year period following the law change. The transition year was left out of any analyses. Belt use among fatalities was also used in the following fashion:

- To compare belt use rates of Caucasians and minorities among the 7 study States. The latter was further broken down into African-American and Other Race. Magnitude of change pre- and post-law was also compared;

- Belt use rates were compared between secondary and primary law States. These were further broken down into use rate by law type across racial groups. This allowed for exploration of a differential effect of law type by race.

FARS data were used to examine change in the proportion of belted fatalities before and after the law upgrade. The pre- and post- periods were tailored specifically to each of the 7 study States. FARS data was classified into two equal periods, "pre-law" (two years before the law change) and "post-law" (two years after the law change). The year of law change was excluded. For instance, if a State upgraded its law in 2005, the pre-period data would consist of fatal crashes occurring in the years 2003 and 2004, whereas the post-period data would consist of fatal crashes occurring in the years 2006 and 2007. A chi-square analysis was used to compare the pre- and the post-period. A binary logistic regression was used to explore for differential effect of the law change across races. 


\section{CITATION DATA}

Details about the number and distribution of seat belt citations were also provided by most participating States across the period reviewed. Belt citations distribution by race were analyzed wherever available. Seat belt citation data were used to track trends in seat belt enforcement and examine variation across years and between races. Law enforcement agencies were contacted and belt citation data were requested for the twoyear period before and after the law change. Efforts were made to obtain the data by race, where available. Data on speeding citations were also collected as a point of comparison. Citation data were used in the following fashion:

- To explore expected variation in level of enforcement before and after the law;

- To compare distribution across race and population size for both speeding and belt citations pre- and post-law.

\section{HOSPITAL DISCHARGE DATA}

Hospital discharge data were requested from individual States and were used to assess changes in number of injuries across years and across races. Where available, data were requested for the two-year period before and after the law change. In cases where race information was not available, race distribution was approximated using ZIP code (based on 2000 Census). Hospital discharge data were used in the following fashion:

- To explore the potential impact of the primary law on number of injuries resulting from motor vehicle crashes;

- To assess whether passage of the law and its associated effects on number of injuries varied among racial groups.

\section{NEWS REPORTS}

News reports about the law change were collected from 6 of the 13 States that upgraded their seat belt law between 2000 and 2009. Full articles were collected using two search engines, LexisNexis and Google News, for the two-year period leading to the law change and were coded for content. In addition, copies of the actual primary seat belt law were obtained for each of the 13 States and were reviewed to determine if the law specifically mentioned race or racial profiling.

Two coders read each article and noted the nature of the report (news or editorial), whether or not racial profiling was mentioned, and whether the article was overall in favor or against primary law upgrade. Inter-rater reliability was assessed. News reports data were used in the following fashion:

- To explore the prevalence of the issue of racial profiling in the debate and if present;

- To explore how various States addressed concerns over racial profiling;

- To assess overall opinion regarding an upgrade to primary law. 


\section{LEGISLATIVE BILLS}

Thirteen States implemented primary seat belt laws between 2000 and 2009. A copy of the law was obtained for each of the 13 States by visiting the State legislature Web site of each included State and was completed by information displayed at www.iihs.org/laws.SafetyBeltUse.aspx. Twelve of 13 States made no mention of racial profiling. A summary of the law for each of the 13 States is provided in Appendix B. 


\section{RESULTS}

The primary purpose of the study was to assess the effects of changing from secondary to primary enforcement status in States that did so since 2000. Data examined included changes in seat belt use, citations and injuries, and whether there were differential effects by race/ethnicity. Before presenting that data, it is useful to look at overall seat belt use in fatally injured front seat occupants by race/ethnicity in secondary versus primary States over the entire 2002-2008 period. Although belt use rates in fatal crashes are lower than observed rates, there is a high degree of correlation $(0.80)$ between the two (Tison, Williams, \& Chaudhary, 2010).

\section{SEAT BELT USE IN FATALITIES}

\section{Primary Versus Secondary Law States}

Data covering the years 2000 to 2008 were collected and compiled for analysis. Belt use rates were compared between States with primary and secondary laws and were further divided by race. Race categories included Caucasian (84\% of fatalities), AfricanAmerican (12\%), and Other (4\%, of which 46\% were Asian, 37\% Native and 17\% multiple races or other). A wider "Minority" category was created which included all non-Caucasian occupants ( $72 \%$ of which were African-Americans). Hispanic origin was not included as a variable since it can apply to any race. Thus in this analysis, persons of Hispanic background could appear in any race category, be it Caucasian, AfricanAmerican or the more general Minority category. Occupants of unknown race were excluded from the analyses. Analyses were limited to known and proper belt use by fatally injured passenger vehicle front seat outboard occupants age 16 and older. For States that changed their seat belt laws, the year of conversion was excluded from the analyses. Chi-square analyses and binary logistic regressions were used as deemed appropriate. Significance level $(\alpha)$ was set at $p<.01$.

An overall comparison of belt use by fatally injured occupants showed that percentage belted was significantly higher in primary States $(52 \%)$ than in secondary States $(37 \%)$. Breaking down the data by race of occupant (Caucasian, minority) showed a similar pattern. Fatally injured Caucasian occupants had significantly higher percentage of belt use in primary States (52\%) than in secondary States (38\%); fatally injured minorities showed $48 \%$ belt use in primary States compared to 31\% in secondary States $(p<.0001)$. A binary logistic regression was computed to determine if the primary/secondary difference was significantly larger for the minority group than the Caucasian group. Results revealed a significant main effect of law type (Wald (1) $=192.69, p<.0001$ ) indicating significantly higher belt use in primary law States than in secondary law States. The main effect of race was also significant (Wald (1) $=200.55$, $p<.0001$ ), indicating greater percentage of belted in Caucasian victims than minority victims. The interaction term also reached significance (Wald $(1)=24.05, p<.0001)$, revealing that there was a bigger difference in primary versus secondary belt use for minority victims than Caucasian victims. This suggests that minorities may reap greater 
benefits from a primary law than non-minorities (see Table 4 for a breakdown of belt use by race).

Table 4. Percentage Belted Fatalities in Primary and Secondary States, by Race, 2000-2008

\begin{tabular}{|r|r|r|r|}
\hline & \multicolumn{1}{|c|}{$\begin{array}{c}\text { Primary } \\
\text { Belt Use }\end{array}$} & $\begin{array}{c}\text { Secondary } \\
\text { Belt Use }\end{array}$ & $\begin{array}{c}\text { \% of Total } \\
\text { Fatalities }\end{array}$ \\
\hline Overall & $51.6 \%$ & $37.2 \%$ & $100 \%$ \\
& $(\mathrm{~N}=97,491)$ & $(\mathrm{N}=91,877)$ & $(\mathrm{N}=189,368)$ \\
\hline Caucasian & $52.4 \%$ & $38.0 \%$ & $85 \%$ \\
& $(\mathrm{~N}=80,595)$ & $(\mathrm{N}=80,289)$ & $(\mathrm{N}=160,884)$ \\
Minority & $48.2 \%$ & $31.2 \%$ & $15 \%$ \\
& $(\mathrm{~N}=16,896)$ & $(\mathrm{N}=11,588)$ & $(\mathrm{N}=28,484)$ \\
\hline African-American & $44.4 \%$ & $30.1 \%$ & $11 \%$ \\
& $(\mathrm{~N}=12,098)$ & $(\mathrm{N}=8,527)$ & $(\mathrm{N}=20,625)$ \\
Other & $57.5 \%$ & $34.4 \%$ & $4 \%$ \\
$(\mathrm{~N}=4,798)$ & $(\mathrm{N}=3,061)$ & $(\mathrm{N}=7,859)$ \\
\hline
\end{tabular}

The minority group was further broken down into an African-American group and an Other group. These two groups also showed a significantly larger percentage of belt use in primary enforcement States than in secondary enforcement States. AfricanAmericans showed a 14-percentage-point difference (44\% belted in primary States versus $30 \%$ in secondary States); the Other group showed a 23-percentage-point difference (from $58 \%$ in primary States to $34 \%$ belted in secondary States). When broken down this way, the law by race interaction was again significant when comparing the Caucasian group to the Other group (Wald $(1)=55.44, p<.0001$. The law by race interaction comparing the Caucasian group to the African-American group was not significant (Wald $(1)=1.47, p>.05)$.

\section{Pre- Versus Post-law Upgrade}

Thirteen States upgraded their laws since 2000. Analyses of effects of law upgrade within the States (i.e., pre- to post-law change) were conducted on a subset of these 13 States. States were selected based on two criteria. First, States were required to have a sufficient pre- and post-law change period (two years pre-, two years post-). As such, States having upgraded their law after 2006 were not included in the FARS analysis. Second, study States were also required to have a sufficiently large minority population. For this reason, Maine and Alaska were excluded due to their relatively homogeneous population. In total, 7 States met the criteria and will be referred to as the study States. They are Delaware, Illinois, Kentucky, Mississippi, South Carolina, Tennessee, and Washington.

Analyses were based on known and proper belt use by fatally injured outboard front seat passenger vehicle occupants, age 16 and above. For each State, specific preand post- periods were identified. The year of law change was excluded from the data, and the two calendar years prior to the change were identified as the pre-upgrade period, whereas the two calendar years following the law change were identified as the post- 
upgrade period. Since not all study States changed their law in the same year, each study State had its own tailored pre- and post- period. Once identified, pre- and post- data were collapsed across the 7 study States. Overall number of fatalities, pre- and post-, were compared across groups to see if minorities showed a larger change in fatalities than the Caucasian group. Percentages of belt use before and after the law change were compared. Furthermore, the magnitude of the change in belt use in various racial groups was examined to assess the presence of a differential effect of the law on majority and minority groups.

The overall number of fatalities in the study States dropped by $8.1 \%$ from pre- to post- upgrade (Table 5), and similar decreases were observed for the major racial groups (race was known in more than $99 \%$ of cases). From pre- to post-, Caucasians showed a $7.4 \%$ decrease in fatalities, the general minority group (i.e., African-Americans and other minorities) showed an $11.3 \%$ decrease in fatalities. The African-American subgroup showed a $10.1 \%$ decrease, and the Other subgroup, representing only $2 \%$ of all fatalities, showed a $19.9 \%$ decrease. Chi-square analyses indicated that the overall decrease in fatalities was significant ( $p<.0001)$, however the magnitude of the decrease did not differ significantly across racial/ethnic groups. That is, Caucasians and minorities showed a similar decrease in number of fatalities pre- to post-law change.

Table 5. Number of Fatalities, Pre- Versus Post-

\begin{tabular}{|l|c|r|r|r|}
\hline & Pre & Post & \% Change & \% Total Fatalities \\
\hline All Fatalities & 8,342 & 7,668 & $-8.1 \%$ & $100 \%$ \\
\hline Caucasian & 6,894 & 6,383 & $-7.4 \%$ & $83 \%$ \\
Minority (incl. African-Am.) & 1,448 & 1,285 & $-11.3 \%$ & $17 \%$ \\
\hline African-American & 1,282 & 1,152 & $-10.1 \%$ & $15 \%$ \\
Other & 166 & 133 & $-19.9 \%$ & $2 \%$ \\
\hline
\end{tabular}

The overall proportion of belt use in fatalities increased by 8 percentage points, from $34 \%$ to $42 \%$, pre- to post-. A chi-square analysis showed this increase to be significant, $p<.0001$. Looking at changes in belt use by race also showed significant increases. Belt use in fatally injured Caucasian occupants increased from $35 \%$ to $44 \%$, a 9 -percentage-point increase $(p<.0001)$. Fatally injured minority occupants showed a significant increase from $30 \%$ to $35 \%$, a 5-percentage-point increase $(p<.01)$. When the minority group was divided further, fatally injured African-American occupants also showed an increase in belt use from $28 \%$ to $32 \%$, pre- to post- $(p=.01)$. The Other group showed a non-significant increase, from $47 \%$ pre-upgrade to $55 \%$ post-upgrade. Table 6 shows the data by State. Caucasians showed an increase in belt use in all 7 States, whereas the minority group showed an increase in 5 of the 7 States. It should be noted that the two States that did not show an increase had a rather small number of minority fatalities; thus those data could be misleading. 
Table 6. Belt Use Among Fatalities, Pre- Versus Post-

\begin{tabular}{|c|c|c|c|c|c|c|c|}
\hline \multirow[t]{2}{*}{ State } & \multirow[t]{2}{*}{ Race } & \multicolumn{2}{|c|}{ Pre } & \multicolumn{2}{|c|}{ Post } & \multirow{2}{*}{$\begin{array}{l}\text { Pre-Post } \\
\text { Change }\end{array}$} & \multirow[t]{2}{*}{ Significance } \\
\hline & & $\mathbf{N}$ & $\%$ & $\mathbf{N}$ & $\%$ & & \\
\hline \multirow[t]{2}{*}{ Delaware } & Caucasian & 142 & $33.8 \%$ & 156 & $55.8 \%$ & +2.2 & $p<.0001$ \\
\hline & Minority & 22 & $50.0 \%$ & 15 & $33.3 \%$ & -16.7 & $N S$ \\
\hline \multirow[t]{2}{*}{ Illinois } & Caucasian & 1,331 & $39.6 \%$ & 1,343 & $51.7 \%$ & +12.1 & $p<.0001$ \\
\hline & Minority & 187 & $36.4 \%$ & 178 & $41.6 \%$ & +5.2 & $N S$ \\
\hline \multirow[t]{2}{*}{ Kentucky } & Caucasian & 1,349 & $33.8 \%$ & 1,066 & $38.7 \%$ & +4.9 & $p=.012$ \\
\hline & Minority & 54 & $42.6 \%$ & 28 & $35.7 \%$ & -6.9 & $N S$ \\
\hline \multirow[t]{2}{*}{ Mississippi } & Caucasian & 897 & $27.0 \%$ & 842 & $36.1 \%$ & +9.1 & $p<.001$ \\
\hline & Minority & 490 & $20.6 \%$ & 415 & $26.7 \%$ & +6.1 & $p=.030$ \\
\hline \multirow{2}{*}{$\begin{array}{l}\text { South } \\
\text { Carolina }\end{array}$} & Caucasian & 939 & $32.8 \%$ & 902 & $38.1 \%$ & +5.3 & $p=.017$ \\
\hline & Minority & 435 & $26.4 \%$ & 369 & $30.9 \%$ & +4.5 & NS \\
\hline \multirow[t]{2}{*}{ Tennessee } & Caucasian & 1,488 & $33.5 \%$ & 1,476 & $39.4 \%$ & +6.0 & $p=.001$ \\
\hline & Minority & 169 & $42.6 \%$ & 190 & $43.2 \%$ & +0.6 & $N S$ \\
\hline \multirow[t]{2}{*}{ Washington } & Caucasian & 748 & $44.3 \%$ & 598 & $63.0 \%$ & +18.7 & $p<.0001$ \\
\hline & Minority & 91 & $45.1 \%$ & 90 & $52.2 \%$ & +7.1 & NS \\
\hline \multirow[t]{2}{*}{ Overall } & Caucasian & 6,894 & $35.0 \%$ & 6,383 & $43.9 \%$ & +8.9 & $p<.0001$ \\
\hline & Minority & 1,448 & $29.8 \%$ & 1,285 & $34.5 \%$ & +4.7 & $p=.008$ \\
\hline
\end{tabular}

The results of a binary logistic regression performed on pre/post- by Caucasian/minority revealed significant main effects for both variables. Post-upgrade belt use was significantly larger than pre-upgrade (Wald $(1)=24.27, p<.0001$ ), and Caucasians had significantly higher belt use than minorities (Wald $(1)=38.72, p<.0001)$. The interaction failed to reach significance. This suggests that the law upgrade did not differentially affect majority and minority groups (see Figure 1). Another logistic regression was performed on pre/post- with race split further into Caucasian, AfricanAmerican, and Other. Results indicated that only the main effect of pre/post- was significant (Wald $(1)=111.09, p<.0001)$. 
Figure 1. Percentage Belted Fatalities Pre-/Post-, by Race 2000-2008

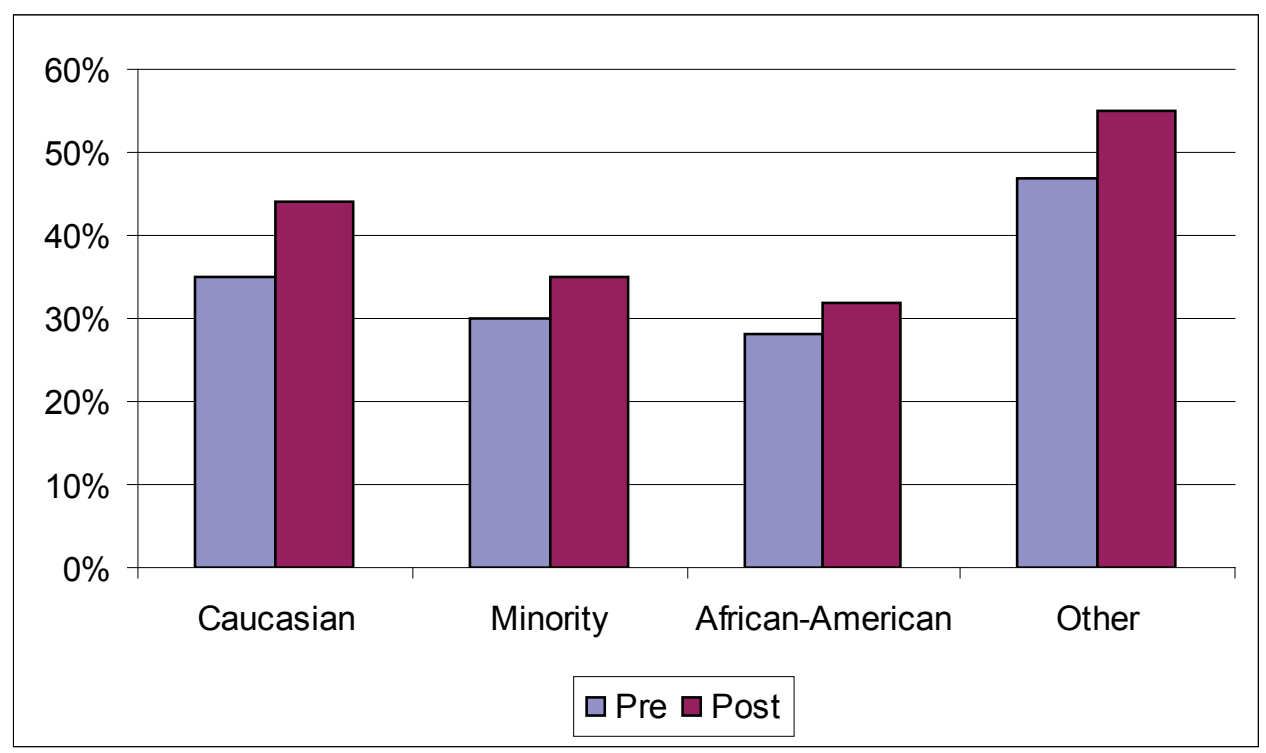

\section{SEAT BELT CITATION DATA}

Seat belt citation data were obtained from 6 of the 13 States that upgraded their law in the period 2000-2009. Number of seat belt citations by race was gathered and analyzed for the States of Kentucky, Mississippi, South Carolina, Tennessee, Illinois, and Florida. All States included seat belt citations, and some included seat belt warning (verbal and/or written). Where available, data on speeding citations were also collected, which were to be used as a point of comparison. Although we attempted to obtain 2 years' worth of data before and after the law upgrade, these were not always available and the length of the pre- and post- periods varies across States. For this reason, each State will be considered separately.

\section{Kentucky}

The Kentucky Department of Public Safety (DPS) provided seat belt and speed citation data for the years 2004 through 2008. The State's primary seat belt law went into effect on July 20, 2006. Thus there were two full years of data prior to the law and two full years of data after the law was in place. Data were provided for the following racial groups: Caucasians, African-Americans, Asian-Americans, and Natives. Totals provided by DPS indicated that these were mutually exclusive groups. Citation recipients whose race/ethnicity was unknown were excluded from the analysis.

\section{Seat Belt Citations}

The year 2007 was the first full calendar year after the law upgrade. Table 7 shows the number of seat belt citations issued in the period from 2004 to 2008. Using 2004 as a baseline, the overall number of citations increased by $95 \%$ in the first year (2007), and $104 \%$ in the second year (2008). Caucasians had a slightly greater percentage 
increase in number of belt citations than did minorities (comprised of African-Americans, Asian-Americans and Natives). Relative to the 2004 baseline, the number of citations issued to Caucasians decreased by $35 \%$ in 2006 (the year of law change), followed by increases of $96 \%$ and $106 \%$ in 2007 and 2008 , respectively; for minorities, there was a decrease of 33\% in 2006, followed by increases of $86 \%$ in 2007 (the first full year after the law change) and $89 \%$ in 2008 . Thus, seat belt citations practically doubled in the two years following the law upgrade. Caucasians and minorities showed an almost identical pattern of change.

Table 7. Kentucky - Number of Seat Belt Citations by Race

\begin{tabular}{lrrrrr|} 
& $\mathbf{2 0 0 4}$ & \multicolumn{1}{c}{$\mathbf{2 0 0 5}$} & \multicolumn{2}{c}{$\mathbf{2 0 0 6}$} & \multicolumn{2}{c}{$\mathbf{2 0 0 7}$} & \multicolumn{1}{c}{$\mathbf{2 0 0 8}$} \\
Caucasian & 39,406 & 38,956 & 25,589 & 77,333 & 81,114 \\
African-American & 4,549 & 4,353 & 3,056 & 8,468 & 8,620 \\
Asian-American & 180 & 189 & 96 & 292 & 259 \\
Native & 10 & 23 & 13 & 43 & 63 \\
Total Minority & 4,739 & 4,565 & 3,165 & 8,803 & 8,942 \\
\multicolumn{1}{c}{ Total } & $\mathbf{4 4 , 1 4 5}$ & $\mathbf{4 3 , 5 2 1}$ & $\mathbf{2 8 , 7 5 4}$ & $\mathbf{8 6 , 1 3 6}$ & $\mathbf{9 0 , 0 5 6}$
\end{tabular}

In $2004,89 \%$ of all seat belt citations were issued to Caucasians. By 2008, the percentage had increased to $90 \%$ ( +1 percentage point). Meanwhile, the percentage of citations issued to minorities went from $11 \%$ in 2004 to $10 \%$ in 2008, a 1-percentagepoint decrease. As a point of comparison, according to the 2008 Census estimates, Caucasians represent $90 \%$ of the population of Kentucky, compared to $10 \%$ for minorities. Thus, the distribution of seat belt citations across racial groups fairly represented the distribution of the overall population and remained stable throughout the period 2004-2008. Table 8 shows the distribution of seat belt citations across race for the entire period 2004 to 2008 .

Table 8. Kentucky - Percentage of Seat Belt Citations Issued by Race

\begin{tabular}{lrrrrr|} 
& $\mathbf{2 0 0 4}$ & $\mathbf{2 0 0 5}$ & $\mathbf{2 0 0 6}$ & $\mathbf{2 0 0 7}$ & $\mathbf{2 0 0 8}$ \\
Caucasian & $89.3 \%$ & $89.5 \%$ & $89.0 \%$ & $89.8 \%$ & $90.1 \%$ \\
African-American & $10.3 \%$ & $10.0 \%$ & $10.6 \%$ & $9.8 \%$ & $9.6 \%$ \\
Asian-American & $0.4 \%$ & $0.4 \%$ & $0.3 \%$ & $0.3 \%$ & $0.3 \%$ \\
Native & $0.0 \%$ & $0.1 \%$ & $0.0 \%$ & $0.0 \%$ & $0.1 \%$ \\
Total Minority & $10.7 \%$ & $10.5 \%$ & $11.0 \%$ & $10.2 \%$ & $9.9 \%$ \\
\multicolumn{1}{c}{ Total } & $\mathbf{1 0 0 \%}$ & $\mathbf{1 0 0 \%}$ & $\mathbf{1 0 0 \%}$ & $\mathbf{1 0 0 \%}$ & $\mathbf{1 0 0 \%}$
\end{tabular}

\section{Speeding Citations}

The total number of speeding citations and distribution across races, for each year from 2004 to 2008, is shown in Table 9. There was an 11\% increase in the number of speeding citations issued from 2004 through 2006, the year of the seat belt law upgrade. 
Post-law change, speeding citations declined. In 2007, they were $13 \%$ lower than in 2004; in 2008, there were 4\% fewer speeding citations than in 2004.

The distribution of speeding citations issued to Caucasians was relatively stable over time, with an average of $88 \%$ of speeding citations being issued to Caucasians and an average of $12 \%$ issued to minorities. The only change in this pattern was in 2007 , the first full year after the seat belt law upgrade, where $84 \%$ of speeding citations were issued to Caucasians and $16 \%$ were issued to minorities. Two years after the law upgrade, the pattern reverted to that seen pre-law change. This distribution was similar to both the distribution of the population of Kentucky as well as the distribution of seat belt citations across race (90\% Caucasian; 10\% Non-Caucasian). If anything, minorities may have been slightly overrepresented in the distribution of speeding citations.

Table 9. Kentucky - Percentage of Speeding Citations Issued by Race

\begin{tabular}{|l|r|r|r|r|r|}
\hline & \multicolumn{1}{|c|}{$\mathbf{2 0 0 4}$} & \multicolumn{1}{c|}{$\mathbf{2 0 0 5}$} & \multicolumn{1}{c|}{$\mathbf{2 0 0 6}$} & \multicolumn{1}{c|}{$\mathbf{2 0 0 7}$} & \multicolumn{1}{c|}{$\mathbf{2 0 0 8}$} \\
\hline Total Speeding Citations & \multicolumn{1}{|c|}{251,537} & 256,931 & 278,086 & 219,753 & 242,033 \\
\hline Caucasian & $88.2 \%$ & $87.8 \%$ & $87.7 \%$ & $84.3 \%$ & $88.3 \%$ \\
African-American & $10.9 \%$ & $11.2 \%$ & $11.4 \%$ & $14.5 \%$ & $10.8 \%$ \\
Asian-American & $0.9 \%$ & $0.9 \%$ & $0.9 \%$ & $1.1 \%$ & $0.9 \%$ \\
Native & $0.0 \%$ & $0.1 \%$ & $0.0 \%$ & $0.1 \%$ & $0.1 \%$ \\
\hline Minority & $11.8 \%$ & $12.2 \%$ & $12.3 \%$ & $15.7 \%$ & $11.7 \%$ \\
\hline
\end{tabular}

\section{Mississippi}

The Mississippi Department of Public Safety provided seat belt and speed citation data for the years 2004 through 2008. The State's primary seat belt law went into effect on May 27, 2006. Thus, there were two full years of data prior to the law change and two full years after the law was in place. Data were provided for the following racial groups: Caucasian, African-American, Asian-American, and Native. Date indicated that these were mutually exclusive groups. Citation recipients whose race/ethnicity was unknown were excluded from all analyses.

\section{Seat Belt Citations}

The year 2007 was the first full calendar year after the law upgrade. Table 10 shows the number of seat belt citations issued in the period from 2004 to 2008 . There was an increase in seat belt citations from 2004 to $2005(+56 \%)$, followed by a much larger increase from 2004 to $2006(+526 \%)$. In the years following the seat belt law upgrade, seat belt citations increased dramatically. Indeed, there was a 1,578\% increase from 2004 to 2007 , and a $1,665 \%$ increase from 2004 to 2008 . Thus, the number of seat belt citations in the two years after the law change was essentially 15 times greater than two years prior to the law change and 11 times greater than the year immediately preceding the law change. 
Caucasians had a larger percentage increase in number of belt citations than did minorities (including African-American, Asian, and Native groups). Relative to the 2004 baseline, the number of citations issued to Caucasians increased by $585 \%$ in 2006 , $1,752 \%$ in 2007 , and $1,832 \%$ in 2008 ; for minorities, there was an increase of $483 \%$ in $2006,1,448 \%$ in 2007 , and $1,640 \%$ in 2008 .

Table 10. Mississippi - Number of Seat Belt Citations by Race

\begin{tabular}{|l|r|r|r|r|r|}
\hline & $\mathbf{2 0 0 4}$ & \multicolumn{1}{c|}{$\mathbf{2 0 0 5}$} & \multicolumn{1}{c|}{$\mathbf{2 0 0 6}$} & \multicolumn{1}{c|}{$\mathbf{2 0 0 7}$} & \multicolumn{1}{c|}{$\mathbf{2 0 0 8}$} \\
\hline Caucasian & 1,005 & 1,711 & 6,881 & 18,610 & 19,420 \\
African-American & 1,312 & 1,926 & 7,742 & 20,626 & 21,664 \\
Asian-American & 0 & 1 & 2 & 18 & 21 \\
Native & 34 & 29 & 99 & 187 & 395 \\
\hline Minority & 1,346 & 1,956 & 7,843 & 20,831 & 22,080 \\
\hline \multicolumn{1}{|c|}{ Total } & $\mathbf{2 , 3 5 1}$ & $\mathbf{3 , 6 6 7}$ & $\mathbf{1 4 , 7 2 4}$ & $\mathbf{3 9 , 4 4 1}$ & $\mathbf{4 1 , 5 0 0}$ \\
\hline
\end{tabular}

In spite of the substantial increase in seat belt citations issued following the law change, the percentage of such citations issued to Caucasians and minorities were consistent over time, with an average of $46 \%$ of all seat belt citations issued to Caucasians and an average of 54\% issued to minorities over the 5-year period (Table 11). More importantly, there was very little variation from before the law change (average $45 \%$ for Caucasians, $55 \%$ minorities) compared to after the law change (average $47 \%$ for Caucasians and $53 \%$ for minorities). The 2008 Census estimates that Caucasians account for $61 \%$ of the population, compared to $39 \%$ for minorities. During the period 2004 to 2008 , relative to the State population, minorities were overrepresented in seat belt ticketing. This trend did not change after seat belt law change.

Table 11. Mississippi - Percentage of Seat Belt Citations Issued by Race

\begin{tabular}{|l|r|r|r|r|r|}
\hline & \multicolumn{1}{|c|}{$\mathbf{2 0 0 4}$} & \multicolumn{1}{|c|}{$\mathbf{2 0 0 5}$} & \multicolumn{1}{c|}{$\mathbf{2 0 0 6}$} & \multicolumn{1}{|c|}{$\mathbf{2 0 0 7}$} & \multicolumn{1}{c|}{$\mathbf{2 0 0 8}$} \\
\hline Caucasian & $42.7 \%$ & $46.7 \%$ & $46.7 \%$ & $47.2 \%$ & $46.8 \%$ \\
African-American & $55.8 \%$ & $52.5 \%$ & $52.6 \%$ & $52.3 \%$ & $52.2 \%$ \\
Asian-American & $0.0 \%$ & $0.0 \%$ & $0.0 \%$ & $0.0 \%$ & $0.1 \%$ \\
Native & $1.4 \%$ & $0.8 \%$ & $0.7 \%$ & $0.5 \%$ & $1.0 \%$ \\
\hline Minority & $57.3 \%$ & $53.3 \%$ & $53.3 \%$ & $52.8 \%$ & $53.2 \%$ \\
\hline \multicolumn{1}{|c|}{ Total } & $\mathbf{1 0 0 \%}$ & $\mathbf{1 0 0 \%}$ & $\mathbf{1 0 0 \%}$ & $\mathbf{1 0 0 \%}$ & $\mathbf{1 0 0 \%}$ \\
\hline
\end{tabular}

\section{Speeding Citations}

The total number of speeding citations and distribution across races, for each year from 2004 to 2008, is shown in Table 12. There was a 10\% increase in the number of speeding citations issued from 2004 through 2006, the year of the seat belt law upgrade. Post-law change, speeding citations continued to increase in 2007 and decline slightly in 2008. In 2007, there were $31 \%$ more speeding citations issued than in 2004; in 2008, there were $16 \%$ more speeding citations issued than in 2004 . 
Table 12. Mississippi - Percentage of Speeding Citations by Race

\begin{tabular}{|l|r|r|r|r|r|}
\hline & \multicolumn{1}{|c|}{$\mathbf{2 0 0 4}$} & \multicolumn{1}{c|}{$\mathbf{2 0 0 5}$} & \multicolumn{1}{c|}{$\mathbf{2 0 0 6}$} & \multicolumn{1}{c|}{$\mathbf{2 0 0 7}$} & \multicolumn{1}{c|}{$\mathbf{2 0 0 8}$} \\
\hline Total Speeding Citations & 126,365 & 95,114 & 139,595 & 165,726 & 146,063 \\
\hline Caucasian & $57.1 \%$ & $56.1 \%$ & $57.5 \%$ & $58.7 \%$ & $58.5 \%$ \\
African-American & $42.5 \%$ & $43.5 \%$ & $42.0 \%$ & $40.9 \%$ & $41.1 \%$ \\
Asian-American & $0.1 \%$ & $0.1 \%$ & $0.1 \%$ & $0.1 \%$ & $0.1 \%$ \\
Native & $0.3 \%$ & $0.3 \%$ & $0.3 \%$ & $0.3 \%$ & $0.3 \%$ \\
\hline Minority & $42.9 \%$ & $43.9 \%$ & $42.5 \%$ & $41.3 \%$ & $41.5 \%$ \\
\hline
\end{tabular}

The distribution of speeding citations issued was relatively stable over time, with an average of $58 \%$ of speeding citations being issued to Caucasians and an average of $42 \%$ issued to minorities. As was the case with seat belt citations, the proportion of speeding citations issued to minorities is a bit higher than would be expected given the race distribution in the State's population. This pattern was similar before and after the seat belt law upgrade.

\section{South Carolina}

In South Carolina, the DPS provided seat belt and speed citation data for the years 2003 through 2008. The State's primary seat belt law went into effect on December 9, 2005. Thus, there were two full years of data prior to the law and three full years of data after the law upgrade. The data were clustered in four racial/ethnic groups: Caucasian, African-American, Hispanic, and Other. Since it was not clear whether "Other" signified "other race" or "race not recorded," this group (less than $1 \%$ of the sample) was eliminated from the analysis. Totals provided by DPS indicated that these were mutually exclusive groups.

\section{Seat Belt Citations}

The year 2006 was the first full calendar year after the law upgrade. Table 13 shows the number of seat belt citations issued in the period from 2003 to 2008. Using 2003 as a baseline, seat belt citations increased by $230 \%$ in 2006 (the first full year following the law change), by $292 \%$ in the second year (2007), and $348 \%$ in the third year (2008). Caucasians had a slightly greater percentage increase in number of belt citations than did minorities (comprised of African-Americans and Hispanics). Relative to the 2003 baseline, the number of citations issued to Caucasians increased by $235 \%$ in $2006,294 \%$ in 2007 , and $357 \%$ in 2008; for minorities, there was an increase of $222 \%$ in $2006,289 \%$ in 2007 , and $335 \%$ in 2008 . 
Table 13. South Carolina - Number of Seat Belt Citations by Race

\begin{tabular}{|l|r|r|r|r|r|r|}
\hline & \multicolumn{1}{|c|}{$\mathbf{2 0 0 3}$} & \multicolumn{1}{|c|}{$\mathbf{2 0 0 4}$} & \multicolumn{1}{|c|}{$\mathbf{2 0 0 5}$} & \multicolumn{1}{|c|}{$\mathbf{2 0 0 6}$} & \multicolumn{1}{|c|}{$\mathbf{2 0 0 7}$} & \multicolumn{1}{c|}{$\mathbf{2 0 0 8}$} \\
\hline Caucasian & 20,687 & 23,663 & 21,557 & 69,262 & 81,452 & 94,448 \\
African-American & 11,383 & 13,117 & 12,453 & 37,456 & 45,704 & 51,191 \\
Hispanic & 1,243 & 1,457 & 1,434 & 3,207 & 3,370 & 3,670 \\
\hline Minority & 12,626 & 14,574 & 13,887 & 40,663 & 49,074 & 54,861 \\
\hline \multicolumn{1}{|c|}{ Total } & 33,313 & 38,237 & 35,444 & 109,925 & 130,526 & 149,309 \\
\hline
\end{tabular}

In spite of the substantial increase in seat belt citations issued following the law change, the distribution of such citations across race was consistent over time, with an average of $62 \%$ of all seat belt citations issued to Caucasians and an average of $38 \%$ issued to minorities over the 6-year period (Table 14). More importantly, there was very little variation from before the law change (average $62 \%$ for Caucasians, $38 \%$ minorities) compared to after the law change (average 63\% for Caucasians and 37\% for minorities). The 2008 Census estimates that Whites (non-Hispanic) account for $65 \%$ of the population, compared to $35 \%$ for minorities or Hispanic. The distribution of seat belt citations across race/ethnicity is thus fairly proportional to the population distribution and remained relatively stable throughout the 2003- to 2008 period.

Table 14. South Carolina - Percentage of Seat Belt Citations Issued by Race/Ethnicity

\begin{tabular}{|l|cccccc|}
\hline & $\mathbf{2 0 0 3}$ & $\mathbf{2 0 0 4}$ & $\mathbf{2 0 0 5}$ & $\mathbf{2 0 0 6}$ & $\mathbf{2 0 0 7}$ & $\mathbf{2 0 0 8}$ \\
\hline Caucasian & $62.1 \%$ & $61.9 \%$ & $60.8 \%$ & $63.0 \%$ & $62.4 \%$ & $63.3 \%$ \\
African-Am. & $34.2 \%$ & $34.3 \%$ & $35.1 \%$ & $34.1 \%$ & $35.0 \%$ & $34.3 \%$ \\
Hispanic & $3.7 \%$ & $3.8 \%$ & $4.0 \%$ & $2.9 \%$ & $2.6 \%$ & $2.5 \%$ \\
\hline Minority & $37.9 \%$ & $38.1 \%$ & $39.2 \%$ & $37.0 \%$ & $37.6 \%$ & $36.7 \%$ \\
\hline \multicolumn{1}{|c|}{ Total } & $\mathbf{1 0 0 \%}$ & $\mathbf{1 0 0} \%$ & $\mathbf{1 0 0} \%$ & $\mathbf{1 0 0 \%}$ & $\mathbf{1 0 0 \%}$ & $\mathbf{1 0 0 \%}$ \\
\hline
\end{tabular}

\section{Speeding Citations}

The total number of speeding citations and distribution across races, for each year from 2003 to 2008, is shown in Table 15. There was a 13\% decline in the number of speeding citations issued from 2003 through 2005 (the year prior to the seat belt law upgrade); followed by a slight increase (4\%) from 2005 through 2008. Thus while there was a slight increase in speeding citations after 2005, the overall numbers remained approximately $7 \%$ below the 2003 levels.

The distribution of citations across Caucasians/minorities was very consistent over time, with an average of $66 \%$ of speeding citations being issued to Caucasians and an average of $34 \%$ issued to minorities. This distribution was similar to both the distribution of the population of South Carolina (65\% White/non-Hispanic; 35\% NonCaucasian/Hispanic) as well as the distribution of seat belt citations across race $(63 \%$ White/non-Hispanic and 37\% non-Caucasian/Hispanic in 2008). 
Table 15. South Carolina - Total Speeding Citations, Percentage by Race

\begin{tabular}{|l|r|r|r|r|r|r|}
\hline & \multicolumn{1}{|c|}{$\mathbf{2 0 0 3}$} & \multicolumn{1}{c|}{$\mathbf{2 0 0 4}$} & \multicolumn{1}{c|}{$\mathbf{2 0 0 5}$} & \multicolumn{1}{c|}{$\mathbf{2 0 0 6}$} & \multicolumn{1}{c|}{$\mathbf{2 0 0 7}$} & \multicolumn{1}{c|}{$\mathbf{2 0 0 8}$} \\
\hline Total Speeding Citations & 230,627 & 232,463 & 200,702 & 213,930 & 222,040 & 209,487 \\
Caucasian & $68.1 \%$ & $67.9 \%$ & $67.0 \%$ & $66.1 \%$ & $66.0 \%$ & $65.6 \%$ \\
African-American & $29.3 \%$ & $29.5 \%$ & $30.1 \%$ & $30.7 \%$ & $30.8 \%$ & $31.1 \%$ \\
Hispanic & $2.6 \%$ & $2.6 \%$ & $2.9 \%$ & $3.2 \%$ & $3.2 \%$ & $3.2 \%$ \\
\hline Minority & $31.9 \%$ & $32.1 \%$ & $33.0 \%$ & $33.9 \%$ & $34.0 \%$ & $34.4 \%$ \\
\hline
\end{tabular}

\section{Tennessee}

The Tennessee Department of Safety (DOS) provides an annual report to the Tennessee General Assembly by fiscal year (October through September) supplying data on total seat belt convictions and total seat belt citations for the Tennessee Highway Patrol (THP). DOS provided reports for the FY 2002-2003 through FY 2007-08. Tennessee implemented its primary law on July 1, 2004 thus, there were close to two full years of data prior to the law (21 months) and four full years of data after the law upgrade. Convictions and citations were provided for six racial/ethnic groups: Caucasian, African-American, Asian-American, Native, Hispanic, and Other. Since it was not clear whether "Other" signified "other race" or "race not recorded," this group (less than 1\% of the sample) was eliminated from the analysis. Totals provided by DOS indicated that these were mutually exclusive groups.

\section{Seat Belt Convictions}

FY 2004-2005 was the first full fiscal year after the law upgrade. Table 16 shows the number of seat belt convictions issued in the period from FY 2002-03 to FY 2007-08. The overall number of convictions declined by 8\% between FY 2002-03 and FY 200304 . The first full fiscal year after the law change showed a dramatic increase in the number of seat belt convictions. Using 2002-03 as a baseline, seat belt convictions increased by 44\% in FY 2004-05 (the first full fiscal year following the law change), by $133 \%$ in the second year (FY 2005-06), 160\% in the third year (FY 2006-07), and 209\% in the fourth year (FY 2007-08).

Table 16. Tennessee - Number of Seat Belt Convictions by Race/Ethnicity

\section{Caucasian \\ Asian-Am. \\ African-Am. \\ Native \\ Hispanic \\ Minority \\ Total}

\begin{tabular}{r|r|r|}
$\mathbf{F Y}$ & \multicolumn{1}{|c|}{$\mathbf{F Y}$} & $\mathbf{F Y}$ \\
$\mathbf{2 0 0 2 - 0 3}$ & $\mathbf{2 0 0 3 - 0 4}$ & $\mathbf{2 0 0 4 - 0 5}$ \\
18,563 & 16,707 & 25,908 \\
85 & 83 & 157 \\
2,802 & 2,802 & 4,651 \\
44 & 50 & 58 \\
551 & 572 & 1,021 \\
3,482 & 3,507 & 5,887 \\
$\mathbf{2 2 , 0 4 5}$ & $\mathbf{2 0 , 2 1 4}$ & $\mathbf{3 1 , 7 9 5}$
\end{tabular}

\begin{tabular}{r|}
$\mathbf{F Y}$ \\
$\mathbf{2 0 0 6 - 0 7}$ \\
$\mathbf{4 5 , 5 8 0}$ \\
265 \\
9,563 \\
97 \\
1,810 \\
11,735 \\
$\mathbf{5 7 , 3 1 5}$
\end{tabular}

FY 2007-08

54,004

431

11,750

137

1,830

14,148

68,152 
Increases in the number of convictions among Caucasians and minorities (comprising African and Asian-Americans, Natives and Hispanics) were $+40 \%$ and $+69 \%$, respectively in the first full FY after implementation of the law. In the second year (FY 2005-06), Caucasians showed a 143\% increase in convictions versus a $77 \%$ increase in minorities (relative to FY 2002-03). Thus, in the two years immediately following the law change, the increases were greater among Caucasians than among minorities. In the third and fourth year post-law, however, the increase in convictions was greater among minorities $(+237 \%$ in FY 2006-07, $+306 \%$ in FY 2007-08) than among Caucasians $(+146 \%$ in FY 2006-07, +191\% in FY 2007-08).

The percentage of convictions among Caucasians averaged $83 \%$ before the law, was $81 \%$ in the first full year post-law and increased to a high of $88 \%$ in FY 2005-06. In the third and fourth year after the law, the proportion of convicted people who were Caucasians decreased to $80 \%$ and $79 \%$ in FY 2006-07 and FY 2007-08, respectively. Accordingly, the proportion of convictions among minorities rose from an average of $17 \%$ pre-law, to an average of $21 \%$ in the third and fourth year after the law was implemented (Table 17). The 2008 Census estimates that Whites (non-Hispanic) account for $77 \%$ of the population, compared to $33 \%$ for non-Caucasians/Hispanics. Thus, although the increase in convictions among minorities in the most recent years may appear troublesome, the distribution of seat belt convictions across race/ethnicity is fairly proportional to the population distribution.

Table 17. Tennessee- Percentage of Seat Belt Convictions by Race/Ethnicity

\begin{tabular}{l|r|r|r|r|r|r} 
& \multicolumn{1}{|c|}{$\mathbf{F Y}$} & $\mathbf{F Y}$ & $\mathbf{F Y}$ & $\mathbf{F Y}$ & $\mathbf{F Y}$ & \multicolumn{1}{|c|}{$\mathbf{F Y}$} \\
& $\mathbf{2 0 0 2 - 0 3}$ & $\mathbf{2 0 0 3 - 0 4}$ & $\mathbf{2 0 0 4 - 0 5}$ & $\mathbf{2 0 0 5 - 0 6}$ & $\mathbf{2 0 0 6 - 0 7}$ & $\mathbf{2 0 0 7 - 0 8}$ \\
Caucasian & $84.2 \%$ & $82.7 \%$ & $81.5 \%$ & $88.0 \%$ & $79.5 \%$ & $79.2 \%$ \\
Asian-Am. & $0.4 \%$ & $0.4 \%$ & $0.5 \%$ & $0.2 \%$ & $0.5 \%$ & $0.6 \%$ \\
African-Am. & $12.7 \%$ & $13.9 \%$ & $14.6 \%$ & $8.7 \%$ & $16.7 \%$ & $17.2 \%$ \\
Native & $0.2 \%$ & $0.2 \%$ & $0.2 \%$ & $0.0 \%$ & $0.2 \%$ & $0.2 \%$ \\
Hispanic & $2.5 \%$ & $2.8 \%$ & $3.2 \%$ & $3.1 \%$ & $3.2 \%$ & $2.7 \%$ \\
Minority & $15.8 \%$ & $17.3 \%$ & $18.5 \%$ & $12.0 \%$ & $20.5 \%$ & $20.8 \%$ \\
\multicolumn{1}{c|}{ Total } & $\mathbf{1 0 0 \%}$ & $\mathbf{1 0 0 \%}$ & $\mathbf{1 0 0 \%}$ & $\mathbf{1 0 0 \%}$ & $\mathbf{1 0 0 \%}$ & $\mathbf{1 0 0 \%}$
\end{tabular}

\section{THP Citations}

A control measure such as speed citations was not available for Tennessee. Instead, seat belt citations issued by the THP provide a second index of enforcement activity. Table 18 shows the number of seat belt citations issued by THP in the period from FY 2002-03 to FY 2007-08. The overall number of citations declined by 3\% between FY 2002-03 and FY 2003-04. The first full fiscal year after the law change showed a large increase in the number of THP seat belt citations. Using 2002-03 as a baseline, citations increased by $62 \%$ in FY 2004-05, by $73 \%$ in the second year (FY 2005-06), 47\% in the third year (FY 2006-07), and 19\% in the fourth year (FY 2007-08). As Table 18 indicates, increases in the number of THP citations among Caucasians and minorities were $+62 \%$ and $+65 \%$, respectively in the first full FY after implementation of the law. In the second year (FY 2005-06), THP citations reached a peak with Caucasians 
showing a $76 \%$ increase in citations versus a $56 \%$ increase in minorities (relative to FY 2002-03). Thus, in the two years immediately following the law change, the increases were slightly larger among Caucasians than among minorities. In the third and fourth year post-law, THP citations started to decline from the peak obtained in 2005-06. The number of THP convictions was still above the baseline level for Caucasians $(+51 \%$ in $2006-07,+24 \%$ in $2007-08$ ). For minorities, THP citations were only $17 \%$ higher in FY 2006-07 and dropped 8\% below the baseline in FY 2007-08.

Table 18. Tennessee - Number of THP Seat Belt Citations by Race/Ethnicity

\begin{tabular}{|l|r|r|r|r|r|r|}
\hline & \multicolumn{1}{|c|}{$\mathbf{F Y}$} & \multicolumn{1}{|c|}{$\mathbf{F Y}$} & \multicolumn{1}{|c|}{$\mathbf{F Y}$} & \multicolumn{1}{|c|}{$\mathbf{F Y}$} & \multicolumn{1}{|c|}{$\mathbf{F Y}$} & \multicolumn{1}{|c|}{$\mathbf{2 Y}$} \\
& $\mathbf{2 0 0 2 - 0 3}$ & $\mathbf{2 0 0 3 - 0 4}$ & $\mathbf{2 0 0 4 - 0 5}$ & $\mathbf{2 0 0 5 - 0 6}$ & $\mathbf{2 0 0 6 - 0 7}$ & $\mathbf{2 0 0 7 - 0 8}$ \\
\hline Caucasian & 25,505 & 24,421 & 41,262 & 44,836 & 38,528 & 31,517 \\
African-American & 2,827 & 3,019 & 4,731 & 4,452 & 3,499 & 2,717 \\
Asian-American & 95 & 27 & 69 & 78 & 47 & 45 \\
Native & 9 & 6 & 15 & 16 & 11 & 19 \\
Hispanic & 991 & 985 & 1,644 & 1,577 & 1,029 & 818 \\
\hline Minority & 3,922 & 4,037 & 6,459 & 6,123 & 4,586 & 3,599 \\
\hline \multicolumn{1}{|c|}{ Total } & $\mathbf{2 9 , 4 2 7}$ & $\mathbf{2 8 , 4 5 8}$ & $\mathbf{4 7 , 7 2 1}$ & $\mathbf{5 0 , 9 5 9}$ & $\mathbf{4 3 , 1 1 4}$ & $\mathbf{3 5 , 1 1 6}$ \\
\hline
\end{tabular}

In FY 2002-03, 87\% of all THP citations were issued to Caucasians. By FY 200708 , the percentage had increased to $90 \%$ ( +3 percentage points). Meanwhile the percentage of citations issued to minorities went from 13\% in FY 2002-03 to $10 \%$ in FY 2007-08, a 3-percentage-point drop. Table 19 shows that the distribution of seat belt citations issued across race remained fairly stable throughout the FY 2002-03 to FY 2007-08 period.

Table 19. Tennessee - Percentage of THP Seat Belt Citations Issued by Race/Ethnicity

\begin{tabular}{|l|r|r|r|r|r|r|}
\hline & \multicolumn{1}{|c|}{$\mathbf{F Y}$} & \multicolumn{1}{|c|}{$\mathbf{F Y}$} & \multicolumn{1}{|c|}{$\mathbf{F Y}$} & \multicolumn{1}{|c|}{$\mathbf{F Y}$} & \multicolumn{1}{|c|}{$\mathbf{F Y}$} & \multicolumn{1}{|c|}{$\mathbf{F Y}$} \\
& $\mathbf{2 0 0 2 - 0 3}$ & $\mathbf{2 0 0 3 - 0 4}$ & $\mathbf{2 0 0 4 - 0 5}$ & $\mathbf{2 0 0 5 - 0 6}$ & $\mathbf{2 0 0 6 - 0 7}$ & $\mathbf{2 0 0 7 - 0 8}$ \\
\hline Caucasian & $86.7 \%$ & $85.8 \%$ & $86.5 \%$ & $88.0 \%$ & $89.4 \%$ & $89.8 \%$ \\
African-American & $9.6 \%$ & $10.6 \%$ & $9.9 \%$ & $8.7 \%$ & $8.1 \%$ & $7.7 \%$ \\
Asian-American & $0.3 \%$ & $0.1 \%$ & $0.1 \%$ & $0.2 \%$ & $0.1 \%$ & $0.1 \%$ \\
Native American & $0.0 \%$ & $0.0 \%$ & $0.0 \%$ & $0.0 \%$ & $0.0 \%$ & $0.1 \%$ \\
Hispanic & $3.4 \%$ & $3.5 \%$ & $3.4 \%$ & $3.1 \%$ & $2.4 \%$ & $2.3 \%$ \\
\hline Minorities & $13.3 \%$ & $14.2 \%$ & $13.5 \%$ & $12.0 \%$ & $10.6 \%$ & $10.2 \%$ \\
\hline \multicolumn{1}{|c|}{ Total } & $\mathbf{1 0 0 \%}$ & $\mathbf{1 0 0 \%}$ & $\mathbf{1 0 0 \%}$ & $\mathbf{1 0 0 \%}$ & $\mathbf{1 0 0 \%}$ & $\mathbf{1 0 0 \%}$ \\
\hline
\end{tabular}

\section{Illinois}

Illinois's primary seat belt law went into effect on July03, 2003. Following passage of the law, the Illinois Department of Transportation (IDOT) was required to monitor seat belt citations. Such data were not tracked prior to that time, according to 
IDOT staff. Thus, data were only available starting in 2004, the first full calendar year following enactment of the law.

IDOT provided the number of seat belt citations, verbal warnings, and written warnings for each year in the 2004-2008 period. The data were clustered in five racial/ethnic groups: Caucasians, African-Americans, Hispanics, Asian/Pacific Islander, and Natives. The data indicate that the groups were mutually exclusive.

\section{Seat Belt Citations}

Since it is the first full calendar year for which data are available, the number of citations issued in 2004 will be used as a baseline for all analyses (see Table 20 for number of seat belt citations issued). Thus, relative to the 2004 baseline, the overall number of citations increased by $14 \%$ in $2005,6 \%$ in 2006, and then decreased in 2007 $(-7 \%)$ and $2008(-1 \%)$. The number of citations issued to Caucasians increased by $12 \%$ in $2005,21 \%$ in $2006,6 \%$ in 2007 and $13 \%$ in 2008. For minorities (comprising AfricanAmerican, Asian-American, Native, and Hispanic), the number of issued citations increased by $17 \%$ in 2005, and then decreased in $2006(-20 \%), 2007(-33 \%)$, and 2008 $(-26 \%)$.

Table 20. Illinois - Number of Seat Belt Citations by Race

\begin{tabular}{|l|r|r|r|r|r|}
\hline & \multicolumn{1}{|c|}{$\mathbf{2 0 0 4}$} & \multicolumn{1}{|c|}{$\mathbf{2 0 0 5}$} & \multicolumn{1}{c|}{$\mathbf{2 0 0 6}$} & \multicolumn{1}{c|}{$\mathbf{2 0 0 7}$} & \multicolumn{1}{c|}{$\mathbf{2 0 0 8}$} \\
\hline Caucasian & 59,449 & 66,850 & 71,823 & 63,276 & 67,312 \\
African-American & 19,334 & 22,230 & 13,226 & 12,098 & 13,663 \\
Asian/Pacific Islander & 1,690 & 2,122 & 2,233 & 1,629 & 1,749 \\
Native & 212 & 218 & 128 & 186 & 213 \\
Hispanic & 11,306 & 13,591 & 10,362 & 7,914 & 8,374 \\
\hline Minority & 32,542 & 38,161 & 25,949 & 21,827 & 23,999 \\
\hline \multicolumn{1}{|c|}{ Total } & $\mathbf{9 1 , 9 9 1}$ & $\mathbf{1 0 5 , 0 1 1}$ & $\mathbf{9 7 , 7 7 2}$ & $\mathbf{8 5 , 1 0 3}$ & $\mathbf{9 1 , 3 1 1}$ \\
\hline
\end{tabular}

In 2004, 65\% of all seat belt citations were issued to Caucasians. By 2008, the percentage had increased to $74 \%$ ( +9 percentage points). Meanwhile, the percentage of citations issued to minorities declined from $35 \%$ in 2004 to $26 \%$ in 2008 , a ninepercentage-point decrease. As a point of comparison, according to the 2008 Census estimates, Whites (non-Hispanic) represented $65 \%$ of the population of Illinois, compared to $35 \%$ for minorities or Hispanics. Starting in 2006, relative to the State population, Whites (non-Hispanic) were overrepresented in seat belt ticketing.

\section{Other Traffic Actions}

Speeding data were also requested. While data specific to speeding were not available, a summary of the total traffic citations and warnings (combined) was provided by IDOT. These data allowed for computation of seat belt versus non-seat belt actions, 
which were used for comparison. Note that the seat belt data may differ from the earlier discussion on seat belt citations since traffic actions include both citations and warnings.

Table 21 indicates that the percentage of seat belt-related actions issued to Caucasians increased over time, from $61 \%$ in 2004 to $74 \%$ in 2008. Conversely, proportion of seat belt-related actions issued to minorities showed a decline over time, from $39 \%$ in 2004 to $27 \%$ in 2008. Distribution of non-seat belt related actions remained stable over time, with an average of $68 \%$ of actions issued to Caucasians, and $32 \%$ issued to minorities.

Table 21. Illinois - Total Traffic Actions, Percentage by Race

\begin{tabular}{|c|c|c|c|c|c|}
\hline & 2004 & 2005 & 2006 & 2007 & 2008 \\
\hline Total Seat Belt Actions & 118,619 & 126,274 & 114,388 & 98,811 & 105,896 \\
\hline Caucasian & $61.4 \%$ & $62.7 \%$ & $73.4 \%$ & $74.0 \%$ & $73.5 \%$ \\
\hline African-American & $23.6 \%$ & $22.4 \%$ & $13.7 \%$ & $14.6 \%$ & $15.3 \%$ \\
\hline Asian/Pacific Islander & $2.1 \%$ & $1.9 \%$ & $2.2 \%$ & $1.9 \%$ & $1.9 \%$ \\
\hline Native & $0.2 \%$ & $0.2 \%$ & $0.1 \%$ & $0.2 \%$ & $0.2 \%$ \\
\hline Hispanic & $12.8 \%$ & $12.8 \%$ & $10.5 \%$ & $9.2 \%$ & $9.1 \%$ \\
\hline Minority & $38.6 \%$ & $37.3 \%$ & $26.6 \%$ & $26.0 \%$ & $26.5 \%$ \\
\hline Total & $100 \%$ & $100 \%$ & $100 \%$ & $100 \%$ & $100 \%$ \\
\hline Total Non-Seat Belt Actions & $2,375,068$ & $2,363,052$ & $2,389,568$ & $2,351,537$ & $2,411,715$ \\
\hline Caucasian & $67.5 \%$ & $68.5 \%$ & $67.7 \%$ & $68.4 \%$ & $67.6 \%$ \\
\hline African-American & $17.2 \%$ & $16.6 \%$ & $17.3 \%$ & $17.2 \%$ & $17.5 \%$ \\
\hline Asian/Pacific Islander & $2.9 \%$ & $2.9 \%$ & $3.0 \%$ & $2.9 \%$ & $3.0 \%$ \\
\hline Native & $0.2 \%$ & $0.2 \%$ & $0.2 \%$ & $0.2 \%$ & $0.2 \%$ \\
\hline Hispanic & $12.1 \%$ & $11.8 \%$ & $11.8 \%$ & $11.2 \%$ & $11.7 \%$ \\
\hline Minorities & $32.5 \%$ & $31.5 \%$ & $32.3 \%$ & $31.6 \%$ & $32.4 \%$ \\
\hline Total & $100 \%$ & $100 \%$ & $100 \%$ & $100 \%$ & $100 \%$ \\
\hline
\end{tabular}

\section{Florida}

Seat belt citation data were obtained from Florida's Uniform Citation System. Florida's primary seat belt law went into effect on June 30, 2009. At the time this report was produced, 2009 data were not yet available, thus only pre-law change data (2006 to 2008 ) are presented. Number of seat belt citations was highest in 2007 , which showed a $16 \%$ increase compared to the previous year. In 2008, the number of citations was $3 \%$ higher than in 2006. Data were obtained for Caucasians, African-Americans, AsianAmericans, Natives, and Hispanics. All groups were mutually exclusive. Caucasians received $63 \%$ of citations in 2006, compared to $58 \%$ and $61 \%$ in 2007 and 2008 , respectively. African-Americans were issued $21 \%$ of citations in each of 2006, 2007, and 2009. Proportion of seat belt citations issued to Hispanics increased by 5 percentage 
points between 2006 and 2007; the 2008 number was 2 percentage points higher than in 2006. Distribution of seat belt citations across race/ethnicity is shown in Table 22.

Table 22. Florida - Percentage of Seat Belt Citations Issued by Race/Ethnicity

\begin{tabular}{|l|r|r|r|}
\hline & \multicolumn{1}{c|}{$\mathbf{2 0 0 6}$} & \multicolumn{1}{c|}{$\mathbf{2 0 0 7}$} & \multicolumn{1}{c|}{$\mathbf{2 0 0 8}$} \\
\hline \multicolumn{1}{|c|}{ Total } & 270,175 & 313,146 & 278,972 \\
\hline Caucasian & $63.0 \%$ & $57.9 \%$ & $60.7 \%$ \\
African-American & $21.3 \%$ & $21.8 \%$ & $21.4 \%$ \\
Asian-American & $0.5 \%$ & $0.6 \%$ & $0.4 \%$ \\
Native & $0.1 \%$ & $0.1 \%$ & $0.1 \%$ \\
Hispanic & $15.1 \%$ & $19.6 \%$ & $17.4 \%$ \\
\hline Minority & $37.0 \%$ & $42.1 \%$ & $39.3 \%$ \\
\hline
\end{tabular}

\section{Citations Summary}

Four States provided seat belt citation data covering the period before and after the law upgrade. The overall distribution of citations across racial/ethnic groups is presented in Table 23. During the pre-period, an average of $11 \%$ of citations were issued to minorities in Kentucky, compared to an average of $10 \%$ after the law upgrade. In Mississippi, minorities were issued $55 \%$ of citations on average in the two years before the law; this declined to $53 \%$ after implementation of the primary seat belt law. In South Carolina, minorities received an average of $38 \%$ of seat belt citations before the law and $37.5 \%$ of citations after the law. The pattern in Tennessee was also stable with minorities being issued $13 \%$ of citations before the law change, and an average of $13 \%$ after the law change. Thus seat belt citation data reveal no real change in pattern of citations across races before and after the law change. Similar data looking at distribution of speeding citations by race can be consulted in Table 24 .

Table 23. Percentage Seat Belt Citations by Race

\begin{tabular}{|l|l|rr|rr|}
\hline \multirow{2}{*}{ State } & \multirow{2}{*}{ Race } & \multicolumn{2}{c|}{ Pre } & \multicolumn{2}{c|}{ Post } \\
\cline { 3 - 6 } & & 2 years & 1 year & 1 year & 2 years \\
\hline Kentucky & Caucasian & $89 \%$ & $90 \%$ & $90 \%$ & $90 \%$ \\
& Minority & $11 \%$ & $10 \%$ & $10 \%$ & $10 \%$ \\
\hline Mississippi & Caucasian & $43 \%$ & $47 \%$ & $47 \%$ & $47 \%$ \\
& Minority & $57 \%$ & $53 \%$ & $53 \%$ & $53 \%$ \\
\hline South Carolina & Caucasian & $62 \%$ & $62 \%$ & $63 \%$ & $62 \%$ \\
& Minority & $38 \%$ & $38 \%$ & $37 \%$ & $38 \%$ \\
\hline Tennessee & Caucasian & n/a & $87 \%$ & $86 \%$ & $88 \%$ \\
& Minority & n/a & $13 \%$ & $14 \%$ & $12 \%$ \\
\hline
\end{tabular}


Table 24. Percentage Speeding Citations by Race

\begin{tabular}{|l|l|rr|rr|}
\hline \multirow{2}{*}{ State } & \multirow{2}{*}{ Race } & \multicolumn{2}{c|}{ Pre } & \multicolumn{2}{c|}{ Post } \\
\cline { 3 - 6 } & & 2 years & 1 year & 1 year & 2 years \\
\hline Kentucky & Caucasian & $88 \%$ & $88 \%$ & $84 \%$ & $88 \%$ \\
& Minority & $12 \%$ & $12 \%$ & $16 \%$ & $12 \%$ \\
\hline Mississippi & Caucasian & $57 \%$ & $56 \%$ & $59 \%$ & $59 \%$ \\
& Minority & $43 \%$ & $44 \%$ & $41 \%$ & $41 \%$ \\
\hline South Carolina & Caucasian & $68 \%$ & $68 \%$ & $66 \%$ & $66 \%$ \\
& Minority & $32 \%$ & $32 \%$ & $34 \%$ & $34 \%$ \\
\hline Tennessee & Caucasian & n/a & n/a & n/a & $\mathrm{n} / \mathrm{a}$ \\
& Minority & n/a & n/a & n/a & n/a \\
\hline
\end{tabular}

\section{CRASH-RELATED INJURY DATA}

The 7 study States were contacted in order to obtain hospital discharge data for each State's pre- and post-law change period. Data from 3 of these States were obtained: Kentucky; South Carolina; and Washington. Injuries to occupants of motor vehicles resulting from motor vehicle crashes were selected using external cause of injury codes ("E codes"). These E codes are diagnosis codes used to identify the source of injuries (e.g., falls, motor vehicle crashes).

Four years of data were obtained from each State: the two years prior to law change, and the two years following the law change (the year of law change was excluded). Thus, two years of data were used in Washington for the pre- period (2000$2001)$ and the post-law-change period (2003-2004). In Kentucky, the pre-law years were 2004 and 2005, and the post-law years were 2007 and 2008. In South Carolina, the prelaw years were 2003 and 2004, and the post-law years were 2006 and 2007.

Ideally, the race of each patient would have been indicated and used to assess any changes in rate of injuries by race from pre- to post-law upgrade. Unfortunately, such data was only available for South Carolina. In Washington and Kentucky, ZIP codes were used as a proxy to race. Race distribution in a given ZIP code (based on 2000 Census data) was used to approximate race distribution in patients admitted from that ZIP code. For instance, if a ZIP code had a high population of African-Americans, it was assumed that a comparable proportion of the patients admitted from that same ZIP code would be African-American. If there is a differential impact of the primary law upgrade across races, patients from predominately Caucasian areas (as determined by ZIP codes) should show a different pre-to-post- change than patients from less predominately Caucasian areas. Actual race was used to explore for differential effects of the law change across race in South Carolina.

\section{Kentucky}

Kentucky had relatively few counties with a substantial non-Caucasian population. As such the comparison was made between ZIP codes where at least $25 \%$ of the population was African-American and those ZIP codes where the population was less 
than 25\% African-American. Even with this very liberal categorization, only 20 of the 768 ZIP codes in Kentucky were classified as "highly" African-American.

In the pre-law upgrade period, there were 5,923 admissions from the high Caucasian ZIP codes and 337 from the high African-American ZIP codes (i.e., 94.6\% of admissions were from high Caucasian ZIP codes). In the post-law period, there were 4,683 admissions from the high Caucasian areas and 250 admissions from the high African-American ZIP code $(94.9 \%$ of admissions came from ZIP codes with a high White population percentage). From pre- to post-, there was a $21 \%$ drop in admissions from the high Caucasian ZIP codes and a 26\% drop in admissions from the high African-

American ZIP codes. This difference in the decreases was not significant $\left(\chi^{2}=0.46, p>\right.$ $.05)$.

\section{Washington}

Washington State had few ZIP codes with a high percentage of African-American residents. As such the analysis was limited to higher and lower Hispanic ZIP codes. In Washington State, ZIP codes with a population greater than $50 \%$ Hispanic were categorized as high Hispanic; those ZIP codes with a population of $50 \%$ or less Hispanic population were labeled as low Hispanic (i.e., high Caucasian) areas. This resulted in 17 of the 569 ZIP codes in the State being high Hispanic.

In the pre- law upgrade period, there were 5,454 admissions from high Caucasian ZIP codes and 202 from high Hispanic ZIP codes (96.4\% high White). In the post period, there were 4,704 admissions from the high Caucasian ZIP codes and 150 from the high Hispanic ZIP codes (96.9\% high Caucasian). There was a 14\% drop in admission from the high Caucasian ZIP codes and a 26\% drop in admission from the Hispanic ZIP codes. This difference was not significant $\left(\chi^{2}=1.87, p>0.05\right)$.

\section{South Carolina}

In South Carolina, where actual race was known, there were 4,833 Caucasian admissions and 2,075 African-American admissions in the 2 years prior to law change. In the two years post-law change there were 4,164 Caucasian admissions and 1,890 African-American admissions. The remaining races (approximately $6 \%$ of the preadmission and $7 \%$ of the post- admissions) were excluded from this analysis. Thus, for the included data, 70\% were Caucasian in the pre- years and $69 \%$ Caucasian in the postyears. There was a 14\% decrease in Caucasian admissions from pre- to post-law change and a $9 \%$ decrease in admissions in African-American admissions. The difference in these decreases was not significant $\left(\chi^{2}=2.12, p>0.05\right)$. 


\section{Conclusion}

In both States where ZIP codes were used as a proxy for actual race there was a greater decrease, albeit non-significant, in the minority admissions than in the Caucasian admissions. In South Carolina, where the actual race was known, there was also a decrease in admissions from pre- to post-law change. The decrease was lower among African-Americans than Caucasian patients, but this difference between races was not significant.

\section{NEWS REPORTS}

The search covered a two-year period prior to the implementation of the law. Two search engines were used, LexisNexis and Google News. The search used the keywords belt (or seatbelt) law, along with race, racial, or minority. Close to 200 news articles were collected from 6 States: Arkansas, Florida, Minnesota, and Wisconsin - all of which upgraded in 2009- as well as Maine and Alaska, which upgraded in 2007 and 2006, respectively. Maine and Alaska provided different views on the primary law debate given their relatively small proportion of minorities.

Each article was read and coded by two independent raters. Raters coded for nature of the article (news or opinion), content (e.g., safety benefits, legislative process, racial profiling), opinions covered (e.g., legislators, civil rights advocates, safety advocates), and overall point of view. A sample of the coding sheet is provided in Appendix B. Analyses were targeted on whether or not racial profiling was mentioned (yes/no) and overall point of view (favorable/unfavorable/both favorable and unfavorable/neutral).

\section{Inter-Rater Reliability}

Inter-rater reliability analyses were performed using the kappa statistics. Analyses were conducted on three elements: nature of the article as news or opinion, mention of racial profiling, and overall point of view. In all cases, inter-rater reliability was highly significant and substantial.

Inter-rater reliability regarding nature of the article was $\mathrm{K}=0.97, \mathrm{p}<.0001$. Raters also agreed strongly on whether or not racial profiling was mentioned, $K=0.99, \mathrm{p}<.0001$. Finally, point of view also showed high inter-rater reliability, with kappa $=0.72, \mathrm{p}<.0001$. On items where the two original coders disagreed, a third coder was introduced as a tiebreaker. The data presented in the following section were thus based on $100 \%$ agreement.

\section{Coding}

The majority of articles collected were judged to be news reports (79\%) and about one fifth $(21 \%)$ were of an editorial nature. Racial profiling was mentioned in $43.5 \%$ of articles (56.5\% made no mention of it). Approximately one third of news reports presented arguments favorable to the primary seat belt law (34\%), 8\% presented 
arguments unfavorable to the primary law upgrade, 35\% reported a balanced view (i.e., judged to present both favorable and unfavorable arguments), and $24 \%$ were neutral.

The distribution of point of view varied greatly between articles that did mention racial profiling and those that did not. For instance, $60 \%$ of articles that mentioned racial profiling were considered to be presenting arguments both favorable and unfavorable to the primary seat belt law compared to only $15 \%$ of articles that did not mention profiling. Furthermore, articles that did not mention racial profiling were considered favorable to the primary law $46 \%$ of the time, compared to just $18 \%$ for those that did mention racial profiling. A chi-square analysis indicated that distribution of point of view was significantly different between articles mentioned racial profiling and those that did not $\left(\chi^{2}=41.60, p<.0001\right)$. Table 25 shows the full distribution of responses.

Table 25. Percentage of Point of View by Racial Profiling

\begin{tabular}{|l|c|c|c|}
\hline \multirow{2}{*}{ Point of View } & \multicolumn{2}{|c|}{ Racial Profiling Mentioned } & \multirow{2}{*}{$\begin{array}{c}\text { Overall } \\
\text { (N=184) }\end{array}$} \\
\cline { 2 - 3 } & Yes (N=80) & No (N=104) & $33.7 \%(\mathrm{~N}=62)$ \\
\hline Favorable & $17.5 \%(\mathrm{~N}=14)$ & $46.2 \%(\mathrm{~N}=48)$ & $7.6 \%(\mathrm{~N}=14)$ \\
\hline Unfavorable & $7.5 \%(\mathrm{~N}=6)$ & $7.7 \%(\mathrm{~N}=8)$ & $34.8 \%(\mathrm{~N}=64)$ \\
\hline $\begin{array}{l}\text { Both Favorable and } \\
\text { Unfavorable }\end{array}$ & $60.0 \%(\mathrm{~N}=48)$ & $15.4 \%(\mathrm{~N}=16)$ & $23.9 \%(\mathrm{~N}=44)$ \\
\hline Neutral & $15.0 \%(\mathrm{~N}=12)$ & $30.8 \%(\mathrm{~N}=32)$ & $\mathbf{1 0 0 . 0 \%}$ \\
\hline \multicolumn{1}{|c|}{ Total } & $\mathbf{1 0 0 . 0 \%}$ & $\mathbf{1 0 0 . 0 \%}$ & \\
\hline
\end{tabular}

There were wide variations between States in percentage of articles mentioning racial profiling. Coverage of this issue was especially prevalent in the States of Wisconsin, Florida, and Arkansas where $68.0 \%, 48.2 \%$, and $47.6 \%$ of articles mentioned racial profiling, respectively. Racial profiling was noted in $42.9 \%$ of articles reviewed in Minnesota. None of the articles reviewed in Alaska and Maine made mention of the issue.

Among the States, $16 \%$ to $42 \%$ of articles reported a favorable view of the seat belt law upgrade, $0 \%$ to $22 \%$ were viewed as unfavorable, $22 \%$ to $39 \%$ reported both favorable and unfavorable arguments, and $15 \%$ to $44 \%$ were considered neutral. Table 26 shows the overall percentages of point of view by State.

Table 26. News Reports: Point of View by State

\begin{tabular}{|l|c|c|c|c|c|}
\hline & $\begin{array}{c}\text { Number of } \\
\text { Articles }\end{array}$ & Favorable & Unfavorable & $\begin{array}{c}\text { Both } \\
\text { Favorable and } \\
\text { Unfavorable }\end{array}$ & Neutral \\
\hline Alaska & 9 & $33 \%$ & $22 \%$ & $22 \%$ & $22 \%$ \\
Arkansas & 21 & $33 \%$ & $5 \%$ & $29 \%$ & $33 \%$ \\
Florida & 85 & $42 \%$ & $5 \%$ & $38 \%$ & $15 \%$ \\
Maine & 16 & $25 \%$ & $0 \%$ & $31 \%$ & $44 \%$ \\
Minnesota & 28 & $29 \%$ & $11 \%$ & $39 \%$ & $21 \%$ \\
Wisconsin & 25 & $16 \%$ & $16 \%$ & $32 \%$ & $36 \%$ \\
\hline \multicolumn{1}{|c|}{ Total } & $\mathbf{1 8 4}$ & $\mathbf{3 4 \%}$ & $\mathbf{8 \%}$ & $\mathbf{3 5 \%}$ & $\mathbf{2 4 \%}$ \\
\hline
\end{tabular}




\section{DISCUSSION}

Earlier research on conversion of seat belt laws to primary enforcement found that Minorities (in most cases African-Americans) perceive stricter enforcement than Caucasians and are more likely to believe they will get a ticket if unbelted. The earlier data show, however, that after the change, the percentage of tickets for nonuse of seat belts received by minorities stays the same, or decreases. Thus there is no evidence for differential enforcement of a primary law, as compared to a secondary law. One possible explanation for the dip in enforcement experience for minorities is that they are more likely to increase their belt use upon the shift to primary. There is some evidence that this occurs, but it is based on self-reports and scattered observational data. Prior data indicate that seat belt use by African-Americans is lower than for Caucasians in secondary States (NHTSA, 2000; Ellis et al, 2000)..

The present study has an advantage over earlier work in that it is based on a greater number of States. The States are located in various regions of the country providing a broad reflection of experience with primary laws in the United States. Since these States have recently changed to primary, they also reflect current practice.

The present study also broadens and extends earlier work. Analyses were based on seat belt use among fatally injured front seat occupants, which is available before and after the change to primary in all States. This belt use measure is closely related to observed seat belt use in potentially fatal crashes, so it is an important indicator. Moreover, observational studies of belt use by race/ethnicity have an unknown error rate in classifying individuals by means of skin color. The present study also attempted to break new ground in using hospital discharge data to make comparisons of changes in injury rates by race/ethnicity on the conversion to primary. Unfortunately, only three States could be included in these analyses.

The results showed clearly the advantages of primary belt laws. Seat belt use in fatalities increased in each of the 7 States studied, with an average gain of 8 percentage points. Significant gains were made among Caucasians, African-Americans, and other minorities. However, the gains were not proportionately greater in the minority groups, and African-Americans had substantially lower belt use than Caucasians both when the laws were secondary and when they were primary. It had been anticipated that AfricanAmericans might have made greater gains than Caucasians. However, this was not the case in the present analyses. It should be noted that belt use in fatalities has been increasing nationwide over the same period, thus it is possible that the increases noted in this report were part of a larger trend.

The highest use of any group was in the "Other Minorities" class, which includes several subgroups that could not be separately identified. Belt use also increased in this group with the change to primary. 
The information on changes in hospital admissions was obtainable from fewer States, but it also showed the advantage of primary laws. In all three States there were sharp drops in admissions for motor vehicle injuries after the switch to primary. AfricanAmericans were the dominant minority in two of these States, Hispanics in the other. Given that there were not differential changes in belt use by race/ethnicity, differential changes in hospital admissions would not be expected. There were decreases in hospital admissions for all groups. A limitation of this analysis is that actual race was only available in one State. Using ZIP code as a proxy for race may be misleading since race distribution was based on the 2000 Census, and race distribution could have changed in the last 10 years.

The numbers of citations for nonuse of seat belts increased substantially in every State that switched to primary, and increases occurred in all groups. However, the percentage of citations received by each group changed very little. Speeding citations, a control series, also showed little change in the proportions cited. Most of the data involved comparisons of Whites and African-Americans, although some States had a code for Hispanics. Both for African-Americans and Hispanics, their share of citations remained about the same before and after the conversion to primary enforcement.

State laws were mostly silent on the subject of differential enforcement. A few of the laws spelled out specific guidelines for enforcement, generally indicating criteria for making stops or what could or could not be done once the stop was made. Only the Florida law called for the establishment of departmental plans designed to prohibit racial profiling practices.

Most of the news articles were favorable about primary laws. Many of the articles mentioned racial profiling, but of those that did, less than $10 \%$ were unfavorable toward primary enforcement.

Primary laws were associated with gains in belt use in all groups, compared to secondary laws. Conversion to primary laws is clearly a forward step in improving injury protection for all drivers. 


\section{REFERENCES}

Benjamin, J. M., Price, G. N., \& Reinfurt, D. (1996). Race and seat belts in North Carolina. Transportation Research Record: Journal of the Transportation Research Board, 1560, 1-7.

Cammisa, M. X., Williams, A. F., \& Ferguson, S. A. (2000). Self-reported belt use in four countries: A telephone survey. Traffic Injury Prevention, 2, 103-110.

Campbell, B. J. (1988). The association between enforcement and seatbelt use. Journal of Safety Research, 19, 159-163.

Dinh-Zarr, T. B., Sleet, D. A., Shults, R. A., Zaza, S., Elder, R. W., Nichols, J. L., ... the Task Force on Community Preventive Services. (2001). Reviews of evidence regarding interventions to increase the use of safety belts. American Journal of Preventive Medicine, 21, 48-65.

Ellis, H. M., Nelson, B., Cosby, O., Morgan, L., Haliburton, W., \& Dew, P. (2000). Achieving a credible health and safety approach to increasing seat belt use among African-Americans. Journal of Health Care for the Poor and Underserved, 11, 144-50.

Farmer, C. M., \& Williams, A. F. (2005). Effect of fatality risk on changing from secondary to primary enforcement. Journal of Safety Research, 36, 189-194.

Glassbrenner, D. (2003, March). Safety Belt Use in 2002-Demographic Characteristics. (DOT HS 809 557) Washington, DC: National Highway Traffic Safety Administration. Available at www-nrd.nhtsa.dot.gov/Pubs/809-557.PDF.

Haseltine, P. (2001). Seat Belt Use in Motor Vehicles: The U.S Experience. 2001 Seat Belt Summit, Orlando, FL.

Hedlund, J., Gilbert, S. H., Ledingham, K. A., \& Preusser, D. F. (2008). How States Achieve High Seat Belt Use Rates. (Final Report. DOT HS 810 962). Washington, DC: National Highway Traffic Safety Administration. Available at wwwnrd.nhtsa.dot.gov/Pubs/810962.PDF.

NHTSA. (2000). Observed Safety Belt Use From December 1999 and June 2000. MiniNOPUS. (Research Note). Washington, DC: National Highway Traffic Safety Administration. Available at www-nrd.nhtsa.dot.gov/Pubs/00025.PDF.

NHTSA. (2008, January). Strengthening Seat Belt Use Laws. (DOT HS 810 890W), Washington, DC: National Highway Traffic Safety Administration. Available at www.nhtsa.gov/DOT/NHTSA/Communication\%20\&\%20Consumer\%20Information/Arti cles/Associated\%20Files/810890.pdf. 
Nichols, J. L. (2005, January). Commentary on "Minorities and Primary Versus Secondary Belt Use Enforcement" In: Implementing Impaired Driving Countermeasures: Putting Research Into Action. Transportation Research Circular, Number E-C072. Washington, DC: Transportation Research Board. Available at http://onlinepubs.trb.org/onlinepubs/circulars/ec072.pdf.

Nichols, J. L. \& Ledingham, K. A. (2008). The Impact of Legislation, Enforcement, and Sanctions on Safety Belt Use. (NCHRP Report 601). Washington, DC: Transportation Research Board. Available at http://onlinepubs.trb.org/onlinepubs/nchrp/nchrp_rpt_601.pdf.

Preusser, D. F., Williams, A. F., \& Lund, A. K. (1991). Characteristics of belted and unbelted drivers. Accident Analysis and Prevention, 23, 475-482.

Preusser, D. F., \& Preusser, C. W. (1997, September). Evaluation of Louisiana's Safety Belt Law Change to Primary Enforcement. (Final Report. DOT HS 808 620). Washington, DC: National Highway Traffic Safety Administration. Available at http://isddc.dot.gov/OLPFiles/NHTSA/009435.pdf.

Reinfurt. D. W. (2000). Memo to the Director of the Governor's Highway Safety Program. Chapel Hill, NC: University of North Carolina Highway Safety Research Center.

Solomon, M. G., Preusser, D. F., \& Nissen, W. J. (2001, March). Evaluation of Maryland, Oklahoma, and the District of Columbia's Seat Belt Law Change to Primary Enforcement. (Final Report. DOT HS 809 213). Washington, DC: National Highway Traffic Safety Administration. Available at www.nhtsa.gov/people/injury/enforce/evaluationlaw.pdf.

Tison, J., Williams, A. F., \& Chaudhary, N. K. (2010, July). Daytime and Nighttime Seat Belt Use by Fatally Injured Passenger Vehicle Occupants. (Final Report. DOT HS 811 281). Washington, DC: National Highway Traffic Safety Administration. Available at http://ntl.bts.gov/lib/33000/33400/33484/Day_vs_Night_Final_PDF.pdf.

Ulmer, R. G., Preusser, C. W., \& Preusser, D. F. (1994). Evaluation of California's Safety Belt Law Change From Secondary to Primary Enforcement. (Final Report. DOT HS 808 205). Washington, DC: National Highway Traffic Safety Administration.

Ulmer, R. G., Preusser, C. W., \& Preusser, D. F. (under review). Evaluation of Georgia's Safety Belt Law Change From Secondary to Primary Enforcement. Final Report. Contract Number DTNH22-94-D-05044. Washington, DC: National Highway Traffic Safety Administration.

Wells, J. K., Williams, A. F., \& Farmer, C. M. (2002). Seat Belt Use Among AfricanAmericans, Hispanics, and Whites. Accident Analysis and Prevention, 34, 523-529. 
Williams, A. F., \& Wells, J. K. (2004). The role of enforcement programs in increasing seat belt use. Journal of Safety Research, 35, 175-180. 
APPENDIX A. STATES BY SEAT BELT LAW ENFORCEMENT STATUS, 1993-2009

\begin{tabular}{|c|c|c|}
\hline & State & Date of Conversion \\
\hline Converted to Primary & $\begin{array}{l}\text { Alabama } \\
\text { Alaska } \\
\text { Arkansas } \\
\text { California } \\
\text { Delaware } \\
\text { District of Columbia } \\
\text { Florida } \\
\text { Georgia } \\
\text { Illinois } \\
\text { Indiana } \\
\text { Kentucky } \\
\text { Louisiana } \\
\text { Maine } \\
\text { Maryland } \\
\text { Michigan } \\
\text { Minnesota } \\
\text { Mississippi } \\
\text { New Jersey } \\
\text { Oklahoma } \\
\text { South Carolina } \\
\text { Tennessee } \\
\text { Washington } \\
\text { Wisconsin }\end{array}$ & $\begin{array}{r}\text { December 9, } 1999 \\
\text { May 1, } 2006 \\
\text { June 30, } 2009 \\
\text { January 1, } 1993 \\
\text { June 30, } 2003 \\
\text { October 1, } 1997 \\
\text { June 30, } 2009 \\
\text { July 1, } 1996 \\
\text { July03, } 2003 \\
\text { July 1, } 1998 \\
\text { July20, } 2006 \\
\text { September 1, } 1995 \\
\text { September20, } 2007 \\
\text { October 1, } 1997 \\
\text { April 1, } 2000 \\
\text { June 9, } 2009 \\
\text { May27, } 2006 \\
\text { May 1, } 2000 \\
\text { November 1, } 1997 \\
\text { December 9, } 2005 \\
\text { July 1, } 2004 \\
\text { July 1, } 2002 \\
\text { June 30, } 2009\end{array}$ \\
\hline Always Secondary & $\begin{array}{l}\text { Arizona } \\
\text { Colorado } \\
\text { Idaho } \\
\text { Kansas } \\
\text { Massachusetts } \\
\text { Missouri } \\
\text { Montana } \\
\text { Nebraska } \\
\text { Nevada } \\
\text { North Dakota } \\
\text { Ohio } \\
\text { Pennsylvania } \\
\text { Rhode Island } \\
\text { South Dakota } \\
\text { Utah } \\
\text { Vermont } \\
\text { Virginia } \\
\text { West Virginia } \\
\text { Wyoming }\end{array}$ & \\
\hline Always Primary & $\begin{array}{l}\text { Connecticut } \\
\text { Hawaii } \\
\text { lowa } \\
\text { New Mexico } \\
\text { New York } \\
\text { North Carolina } \\
\text { Oregon } \\
\text { Texas }\end{array}$ & \\
\hline No Law & New Hampshire & \\
\hline
\end{tabular}




\section{APPENDIX B: LEGISLATIVE BILLS}

ALASKA: The primary law came in effect on May 1, 2006, and applies to all occupants 16 and older. It states that a person " 16 years of age or older may not occupy a motor vehicle while being driven on a highway unless restrained by a safety belt" and a person "may not drive a motor vehicle on a highway unless restrained by a safety belt." The law further states that "a driver may not transport a child under the age of 16 in a motor vehicle unless the driver has provided the required safety device and properly secured each child." The maximum fine for a first offense is $\$ 15$ and nonuse can decrease injuryrelated monetary awards in a lawsuit. The law states that "a peace officer may not stop or detain a motor vehicle to determine compliance" with the seat belt law or may not issue a citation for a seat belt violation "unless the peace officer has probable cause to stop or detain the motor vehicle."

ARKANSAS The primary law became effective on June 30, 2009, and applies to front seat occupants 15 and older. The maximum fine for a first offense is $\$ 25$ and nonuse cannot decrease injury-related monetary awards in a lawsuit. The law states that "each driver and front seat passenger in any motor vehicle operated on a street or highway in this State shall wear a properly adjusted and fastened seat belt properly secured to the vehicle". Furthermore, "no motor vehicle, nor the operator or such vehicle, nor the passengers of such vehicle shall be stopped, inspected, or detained solely to determine compliance" with this law.

DELAWARE: The primary law came into effect on June 30, 2003, and applies to all occupants 16 and older. The maximum fine for a first offence is $\$ 25$ and nonuse cannot decrease injury-related monetary awards in a lawsuit. The law states that "any police officer is authorized to make an administrative stop for purposes of enforcing $<$ this law $>$ upon reasonable and articulable suspicion that a violation" of the law has occurred.

FLORIDA: The primary law came into effect on June 30, 2009, and applies to front seat occupants 6 and older and to all occupants age of 6 to 17. The maximum fine for a first offense is $\$ 30$ and nonuse can decrease injury-related monetary awards in a lawsuit. The law states that it is unlawful for any person "to operate a motor vehicle in this State unless each passenger and the operator of the vehicle under the age of 18 years are restrained by a safety belt or by a child restraint device" or "to operate a motor vehicle in this State unless the person is restrained by a safety belt." The law further states that "it is unlawful for any person 18 years of age or older to be a passenger in the front seat of a motor vehicle unless such person is retained by a safety belt when the vehicle is in motion." Moreover, "each law enforcement agency in this State shall adopt departmental policies to prohibit the practice of racial profiling."

ILLINOIS: The primary law became effective on July 03, 2003, and applies to front seat occupants 16 and older. When the driver is younger than 18, the law applies to all occupants 18 and younger. The maximum fine for a first offense is $\$ 25$ and nonuse cannot decrease injury-related monetary awards in a lawsuit. The law states that "each driver and front seat passenger of a motor vehicle operated on a street or highway in this State shall wear a properly adjusted and fastened seat belt..."; also "each driver under the 
age of 18 years and each of the driver's passengers under the age of 18 years of a motor vehicle operated on a street or highway in this State shall wear a properly adjusted and fastened seat safety belt. Each driver of a motor vehicle transporting a child 8 years of age or more, but less than 16 years of age, shall secure the child in a properly adjusted and fastened seat belt." The law further states that a "law enforcement officer may not search or inspect a motor vehicle, its contents, the driver, or a passenger solely because of a violation of this section."

KENTUCKY: The primary law went into effect on July 20, 2006, and applies to all occupants 7 and older, and to all occupants 6 and under with a height of more than 50 inches. The maximum fine for a first offense is $\$ 25$ and nonuse cannot decrease injuryrelated monetary awards in a lawsuit. The law states that "a person shall not operate a motor vehicle manufactured after 1981 on the public roadways of this State unless the driver and all passengers are wearing a properly adjusted and fastened seat belt."

MAINE: The primary law came into effect on September 20,2007, and applies to all occupants 18 and over. The maximum fine for a first offense is $\$ 50, \$ 125$ for the second offense and $\$ 250$ for the third and subsequent offences. Nonuse cannot decrease injuryrelated monetary awards in a lawsuit. The law states that "when a person 18 years of age or older is a passenger in a vehicle that is required by the United States Department of Transportation to be equipped with seat belts, the passenger must be properly secured in a seat belt."; also the "operator of a vehicle that is required by the United States Department of Transportation to be equipped with seat belts must be secured in the operator's seat belt." Furthermore, a "fine imposed under this subsection may not be suspended by the court. A vehicle, the contents of a vehicle, the driver of or a passenger in a vehicle may not be inspected or searched solely because of a violation" of this law.

MINNESOTA: The primary seat belt law came into effect on June 9, 2009, and applies to all occupants 8 and older and to occupants 7 and younger who are more than 57 inches. The maximum fine for a first offense is $\$ 25$. Nonuse cannot decrease injury-related monetary awards in a lawsuit. The law states that a properly adjusted and fastened seat belt shall be worn by "the driver and passengers of a passenger vehicle, commercial vehicle, type III vehicle, and type III Head Start vehicle."

MISSISSIPPI: The primary seat belt law became effective on May27, 2006, and applies to front seat occupants 7 and older. The maximum fine for a first offense is $\$ 25$ and nonuse cannot decrease injury-related monetary awards in a lawsuit. The law states that "only the operator of the vehicle may be fined for a violation of this chapter by the operator or by any passenger. The maximum fine that may be imposed against the operator of a vehicle for a violation of this chapter by the operator or for a violation of this chapter by one of more passengers shall be $\$ 50$ in the aggregate." The law further states that "when a passenger motor vehicle is operated in forward motion on a public road, street or highway within this State, every front-seat passenger and every child who is at least four years of age but under eight years of age, regardless of the seat such child occupies, shall wear a properly fastened safety belt system." 
SOUTH CAROLINA: The primary seat belt law went into effect on December 9, 2005, and applies to front seat occupants 6 and older and to those 6 and older in rear seats with shoulder belt. The maximum fine for a first offense is $\$ 25$ and nonuse cannot decrease injury-related monetary awards in a lawsuit. The law states that the "driver and every occupant of a motor vehicle, when it is being operated on the public streets and highways of this State, must wear a fastened safety belt." Furthermore, "the driver is charged with the responsibility of requiring each occupant [17] years of age or younger to wear a safety belt or be secured in a child restraint system (...). However, a driver is not responsible for an occupant [17] years of age or younger who has a driver's license, special restricted license, or beginner's permit and who is not wearing a seat belt." According to the law, a "law enforcement officer must not issue a citation to a driver or a passenger for a violation of this article when the stop is made in conjunction with a driver's license check, safety check or registration check conducted at a checkpoint." The law further states that "a vehicle, driver, or occupant in a vehicle must not be searched, nor may consent to search be requested by a law enforcement officer, solely because of a violation of this article." Also, "a law enforcement officer must not stop a driver for a violation of this article except when the officer has probably cause that a violation has occurred based on his [sic] clear and unobstructed view of a driver or an occupant of the motor vehicle who is not wearing a safety belt or is not secured in a child restraint system."

TENNESSEE: The primary seat belt law became effective on July 1, 2004, and applies to front seat occupants 16 and older. The maximum fine for a first offense is $\$ 50$ and nonuse cannot decrease injury-related monetary awards in a lawsuit. The law states that "no person shall operate a passenger motor vehicle on any highway (...) in this State unless such person and all passengers four years of age or older are restrained by a safety belt at all times the vehicle is in forward motion." Also "the provisions of this section shall apply only to the operators and all passengers occupying the front seat of a passenger motor vehicle." Regarding fines, the law indicates that "a person charged with a violation of this section may, in lieu of appearance in court, submit a fine of [\$10.00] for a first violation, and [\$20.00] on second and subsequent violations..." The law further states that "a law enforcement officer observing a violation of this section shall issue a citation to the violator, but shall not arrest or take into custody any person solely for a violation of this section."

WASHINGTON: The primary seat belt law went into effect on July 1, 2002, and applies to all front seat occupants 16 and over. The maximum fine for a first offense is $\$ 124$ and nonuse cannot decrease injury-related monetary rewards in a law suit. The law states that "every person [16] or older operating or riding in a motor vehicle shall wear the safety belt assembly in a properly adjusted and securely fastened manner."

WISCONSIN: The primary seat belt law went into effect on June 30, 2009, and applies to all occupants 8 and older. The maximum fine for a first offense is $\$ 10$ and nonuse can decrease injury-related monetary awards in a lawsuit. The law states that if a "motor vehicle is required to be equipped with safety belts in this State, no person may operate that motor vehicle unless the person is properly restrained in a safety belt." Also, if a 
"motor vehicle is required to be equipped with safety belts in this State, no person may operate that motor vehicle unless each passenger who is at least 8 years old and who is seated at a designated seating position in the front seat required ... to have a safety belt installed or at a designated seating position in the seats, other than the front seats, for which a safety belt is required to be installed may be a passenger in that motor vehicle unless the person is properly restrained." The law further states that "a law enforcement officer may not stop or inspect a vehicle solely to determine compliance with this subsection (...). This paragraph does not limit the authority of a law enforcement officer to issue a citation for a violation of this subsection ... observed in the course of a stop or inspection made for other purposes, except that a law enforcement officer may not take a person into physical custody solely for a violation of this subsection (...)." 


\section{APPENDIX C. NEWS REPORTS CODING SHEET}

\begin{tabular}{|c|c|}
\hline \multicolumn{2}{|c|}{ Item Description (used for tracking only) } \\
\hline $\begin{array}{l}\text { Item number } \\
\text { State } \\
\text { Date published } \\
\text { Headline } \\
\text { Source } \\
\text { Type (News/Opinion) }\end{array}$ & \\
\hline \multicolumn{2}{|c|}{ Content (check all that apply) } \\
\hline $\begin{array}{l}\text { Legislative process } \\
\text { Safety benefits } \\
\text { Economic benefits } \\
\text { Seat belt use rate } \\
\text { Enforcement campaign } \\
\text { Racial profiling } \\
\text { Civil rights }\end{array}$ & \\
\hline \multicolumn{2}{|c|}{ Opinions Covered (check all that apply) } \\
\hline $\begin{array}{l}\text { Legislators } \\
\text { Safety advocates } \\
\text { Law enforcement officials } \\
\text { Civil rights advocates } \\
\text { Other }\end{array}$ & \\
\hline \multicolumn{2}{|c|}{ Point of View (check one) } \\
\hline $\begin{array}{l}\text { Favorable } \\
\text { Unfavorable } \\
\text { Both favorable and unfavorable } \\
\text { Neutral }\end{array}$ & \\
\hline
\end{tabular}



DOT HS 811535

September 2011

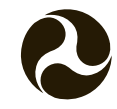

U.S. Department of Transportation

National Highway Traffic Safety Administration

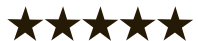
NHTSA www.nhtsa.gov 